NBER WORKING PAPERS SERIES

\title{
INTERTEMPORAL ASSET PRICING WITHOUT CONSUMPTION DATA
}

\author{
John Y. Campbell
}

Working Paper No. 3989

\section{NATIONAL BUREAU OF ECONOMIC RESEARCH 1050 Massachusetts Avenue Cambridge, MA 02138 \\ February 1992}

I am grateful to the LSE Financial Markets Group for its hospitality during the academic year 1989-90, to the National Science Foundation and the Sloan Foundation for financial support, and to Kevin Carey and Hyeng Keun Koo for able research assistance. Andrew Abel, Fischer Black, Doug Breeden, Steve Cecchetti, John Cochrane, George Constantinides, Silverio Foresi, Ravi Jagannathan, Bob Merton, Lars Svensson, Philippe Weil, Steve Zeldes, and two referees made helpful comments on earlier drafts, which carried the title "Intertemporal Asset Pricing Without Consumption." This paper is part of NBER's research programs in Asset Pricing and Economic Fluctuations. Any opinions expressed are those of the author and not those of the National Bureau of Economic Research. 
NBER Working Paper \#3989

February 1992

\section{INTERTEMPORAL ASSET PRICING WITHOUT CONSUMPTION DATA}

\section{ABSTRACT}

This paper proposes a new way to generalize the insights of static asset pricing theory to a multi-period setting. The paper uses a loglinear approximation to the budget constraint to substitute out consumption from a standard intertemporal asset pricing model. In a homoskedastic lognormal setting, the consumption-wealth ratio is shown to depend on the elasticity of intertemporal substitution in consumption, while asset risk premia are determined by the coefficient of relative risk aversion. Risk premia are related to the covariances of asset returns with the market return and with news about the discounted value of all future market returns.

John Y. Campbell

Woodrow Wilson School

Princeton University Princeton, NJ 08544-1013 and NBER 


\section{Introduction}

For the last twenty years an important goal of financial research has been to generalize the insights of the simple one-period Capital Asset Pricing Model (CAPM) to a multi-period setting. Such a generalization is difficult to achieve because the multiperiod consumption and portfolio choice problem is inherently nonlinear. A complctc solution is obtained by combining the consumer's Euler equation with the intertemporal budget constraint, but the budget constraint is a nonlinear equation except in very special cases.

In response to this difficulty Merton $(1969,1971,1973)$ suggested reformulating the consumption and portfolio choice problem in continuous time. Doing this in effect linearizes by taking the decision interval as infinitely small, so that the model becomes linear over this interval. But this kind of linearity is only local, so it does not allow one easily to study longer-run aspects of intertemporal asset pricing theory.

In this paper I take a different approach. Instead of assuming that the time interval is small, I assume that variation in the consumption-wealth ratio is small. This makes the intertemporal budget constraint approximately loglinear, allowing me to solve the consumption and portfolio choice problem in closed form. My approach clarifies the relation between the time-series properties of market returns and the timeseries properties of consumption. It also leads to a simple expression relating assets' risk premia to their covariances with the market return and news about future market returns. This formula unifies the large body of research on time-series properties of aggregate stock returns with the equally large literature on cross-sectional patterns of mean returns.

The formula for risk premia derived in this paper can be tested without using data on consumption. This is potentially an important advantage, for empirical work using aggregate consumption data has generally rejected the model restrictions or has estimated implausible parameter values. These problems occur both with a simple power specification for utility (Hansen and Singleton 1982, 1983, Mehra and Prescott 1985, Mankiw and Shapiro 1986) and with more elaborate specifications that allow for habit formation (Constantinides 1990, Ferson and Constantinides 1991) or for a divergence between the coefficient of relative risk aversion and the elasticity of intertemporal substitution (Epstein and Zin 1989, 1991, Giovannini and Jorion 1989, Weil 1987, 1989). The difficulty may well be inherent in the use of aggregate consumption data. These 
data are measured with error and are time aggregated, which can have serious consequences for asset pricing relationships (Breeden, Gibbons, and Litzenberger 1989, Grossman, Melino, and Shiller 1987, Heaton 1990, Wheatley 1989, Wilcox 1989). More fundamentally, the consumption of asset market participants may be poorly proxied by aggregate consumption. Predictable movements in aggregate consumption growth are correlated with predictable growth in current disposable income, which suggests that a large fraction of the population is liquidity-constrained or fails to optimize intertemporally (Campbell and Mankiw 1989), and micro evidence shows that the consumption of stockholders behaves differently from the consumption of non-stockholders (Mankiw and Zeldes 1991).

Of course, the approach of this paper does not resolve all measurement issues. The formula for risk premia derived here requires that one be able to measure the return on the market portfolio, which should in general include human capital. The difficulties with this have been forcefully pointed out by Roll (1977) in his critique of tests of the static CAPM. But at the very least the results of the paper enable one to use the imperfect data on both market returns and consumption in new and potentially fruitful ways.

The next section of this paper shows how to obtain a loglinear approximation to the intertemporal budget constraint. Section 3 develops implications for asset pricing when asset returns are jointly lognormal and homoskedastic, and when consumers have the objective function proposed by Epstein and Zin (1989, 1990) and Weil (1987). This objective function implies that the consumption-wealth ratio is constant whenever the intertemporal elasticity of substitution is equal to one, so it provides a natural benchmark case in which the loglinear approximation of this paper holds exactly. Importantly, the intertemporal asset pricing model differs from a one-period asset pricing model even in this benchmark case. This section of the paper derives several alternative expressions for risk premia and discusses how they might be tested empirically. Section 4 allows for changing second moments of asset returns. Section 5 assesses the accuracy of the approximation to the intertemporal budget constraint, and section 6 concludes. 


\section{A Loglinear Approximation to the Intertemporal Budget Constraint}

I consider a representative agent economy in which all wealth, including human capital, is tradable. I define $W_{t}$ to be total wealth, including human capital, at the beginning of period $t, C_{t}$ to be consumption at time $t$, and $R_{m, t+1}$ to be the gross simple return on wealth invested from period $t$ to period $t+1$. The subscript $m$ denotes the fact that total invested wealth is the "market portfolio" of assets. The representative agent's dynamic budget constraint can then be written as

$$
W_{t+1}=R_{m, t+1}\left(W_{t}-C_{t}\right)
$$

Labor income does not appear explicitly in this budget constraint because of the assumption that the market value of tradable human capital is included in wealth. The budget constraint can be solved forward, imposing a condition that the limit of discounted future wealth is zero, to obtain the highly nonlinear present value budget constraint

$$
W_{t}=C_{t}+\sum_{i=1}^{\infty} \frac{C_{t+i}}{\left(\prod_{j=1}^{i} R_{m, t+j}\right)}
$$

The loglinear approximation begins by dividing (2.1) through by $W_{t}$, to obtain

$$
\frac{W_{t+1}}{W_{t}}=R_{m, t+1}\left(1-\frac{C_{t}}{W_{t}}\right)
$$

or in logs (indicated by lower-case letters)

$$
\Delta w_{t+1}=r_{m, t+1}+\log \left(1-\exp \left(c_{t}-w_{t}\right)\right)
$$

The second term on the right hand side is a nonlinear function of the log consumptionwealth ratio. Consider this as a function of some variable $x_{t}=\log \left(X_{t}\right)$, and take a first-order Taylor expansion around the mean $\bar{x}$. The resulting approximation is

$$
-3-
$$




$$
\log \left(1-\exp \left(x_{t}\right)\right) \approx \log (1-\exp (\bar{x}))-\frac{\exp (\bar{x})}{1-\exp (\bar{x})}\left(x_{t}-\bar{x}\right)
$$

If $x_{t}$ is a constant $x=\log (X)$, then the coefficient $-\exp (\bar{x}) /(1-\exp (\bar{x}))$ equals $-X /(1-X)$. In the present application, when the log consumption-wealth ratio is a constant the coefficient equals $-C /(W-C)$, the constant ratio of consumption to invested wealth. Of course, when $x_{t}$ is random then by Jensen's Inequality the coefficient no longer equals the average ratio of consumption to invested wealth.

Figures 1 and 2 give a visual impression of the approximation (2.5). In each figure the horizontal axis measures the consumption-wealth ratio, using a log scale. The vertical axis measures the "net growth rate of wealth", that is the growth rate of wealth less the market return $\Delta w_{t+1}-r_{m, t+1}$. The solid line shows the exact relationship $\Delta w_{t+1}-r_{m, t+1}=\log \left(1-\exp \left(c_{t}-w_{t}\right)\right)$, while the dashed straight line shows the approximation (2.5). These lines are plotted over a horizontal range three standard deviations on either side of the mean log consumption-wealth ratio, where the standard deviation of the log consumption-wealth ratio is calculated for an example calibrated in section 5 below using equation (5.2). Figure 1 assumes that the consumer has an elasticity of intertemporal substitution in consumption equal to 2 (or zero, since the standard deviation of the log consumption-wealth ratio depends on the distance of this elasticity from one), while Figure 2 assumes an elasticity of intertemporal substitution equal to 4. In this example the approximation is clearly very accurate when the variability of the log consumption-wealth ratio is as low as implied by an elasticity of 2 , but much less accurate when the variability is as high as implied by an elasticity of 4 . Section 5 of the paper discusses approximation accuracy in greater detail.

It will be helpful to rewrite the coefficient $-\exp (\bar{x}) /(1-\exp (\bar{x}))$ in $(2.5)$ as $1-1 / \rho$ where $\rho \equiv 1-\exp (\bar{x})$. When the log consumption-wealth ratio is constant, then $\rho$ can be interpreted as $(W-C) / W$, the constant ratio of invested wealth to total wealth. Putting together (2.4) and (2.5), the approximation to the intertemporal budget constraint is

$$
\Delta w_{t+1} \approx r_{m, t+1}+k+\left(1-\frac{1}{\rho}\right)\left(c_{t}-w_{t}\right)
$$

where the constant $k$ can be calculated directly from (2.5).

The next step is to use the trivial equality 


$$
\Delta w_{t+1}=\Delta c_{t+1}+\left(c_{t}-w_{t}\right)-\left(c_{t+1}-w_{t+1}\right)
$$

Equating the left hand sides of (2.6) and (2.7), one obtains a difference equation in the $\log$ consumption-wealth ratio, $c_{t}-w_{t}$. This can be solved forward, assuming that $\lim _{j \rightarrow \infty} \rho^{j}\left(c_{t+j}-w_{t+j}\right)=0$, to yield

$$
c_{t}-w_{t}=\sum_{j=1}^{\infty} \rho^{j}\left(r_{m, t+j}-\Delta c_{t+j}\right)+\frac{\rho k}{1-\rho} .
$$

This equation is the loglinear equivalent of the nonlinear expression (2.2). It says that a high consumption-wealth ratio today must be followed either by high returns on invested wealth, or by low consumption growth. This holds simply by virtue of the intertemporal budget constraint; there is no model of optimal behavior in equation (2.8).

Equation (2.8) holds ex post, but it also holds ex ante; if one takes expectations of (2.8) at time $t$, the left hand side is unchanged and the right hand side becomes an expected discounted value:

$$
c_{t}-w_{t}=E_{t} \sum_{j=1}^{\infty} \rho^{j}\left(r_{m, t+j}-\Delta c_{t+j}\right)+\frac{\rho k}{1-\rho} .
$$

Equation (2.9) can be substituted into (2.6) and (2.7) to obtain

$$
\begin{aligned}
c_{t+1}-E_{t} c_{t+1} & =\left(E_{t+1}-E_{t}\right) \sum_{j=0}^{\infty} \rho^{j} r_{m, t+1+j} \\
& -\left(E_{t+1}-E_{t}\right) \sum_{j=1}^{\infty} \rho^{j} \Delta c_{t+1+j}
\end{aligned}
$$

Equation (2.10) says thet an upward surprise in consumption today must correspond to an unexpected return on wealth today (the first term in the first sum on the right hand 
side of the equation), or to news that future returns will be higher (the remaining terms in the first sum), or to a downward revision in expected future consumption growth (the second sum on the right hand side). This is similar to the equation discussed in Campbell (1991a) for an arbitrary stock portfolio. Here consumption plays the role of dividends in the earlier analysis; aggregate wealth can be thought of as an asset whose dividends are equal to consumption. In the next section, a loglinear Euler equation will be used to eliminate expected future consumption growth from the right hand side of (2.10), leaving only current and expected future asset returns. 


\section{Intertemporal Asset Pricing with Constant Variances}

In this section I explore asset pricing relationships assuming that the conditional joint distribution of asset returns and consumption is homoskedastic. This assumption is unrealistic, since there is strong evidence that asset return variances change through time, but it simplifies the analysis considerably. In the next section I allow for heteroskedasticity.

The loglinear approximate budget constraint of the previous section can be combined with a loglinear Euler equation. To obtain such an Euler equation, I further assume that the joint conditional distribution of asset returns and consumption is lognormal. Below I show that this is an approximate implication of the more fundamental assumption that returns and news about future returns are jointly lognormal. The lognormality assumption can also be relaxed if one is willing to work with a second-order Taylor approximation to the Euler equation. ${ }^{1}$

Along with these distributional assumptions, I use the non-expected utility model proposed by Epstein and Zin $(1989,1991)$ and Weil (1987) to generate a loglinear Euler equation that distinguishes the coefficient of relative risk aversion and the elasticity of intertemporal substitution. In the standard model of time-separable power utility, relative risk aversion is the reciprocal of the elasticity of intertemporal substitution, but as we shall see these concepts play quite different roles in the asset pricing theory. The non-expected utility model also allows intertemporal considerations to affect asset prices even when the consumption-wealth ratio is constant, something which is not possible with time-separable power utility.

\footnotetext{
1 Conditional joint lognomality and homoakedasticity are also ecoumed by Hansen and Singkton (1983). Note that conditional lognormality does not imply unconditional lognomality unleas conditional expected returno are conatant through time. Constant expected return and unconditional lognomnality are asaumed in Merton's (1969, 1971) contimuous-time model, where all aset retums follow geometric Bromian motion; the assumption used here is weaker.
} 


\subsection{The Euler Equation for a Simple Non-Expected Utility Model}

The objective function for a simple non-expected utility model is defined recursively by

$$
\begin{aligned}
U_{t} & =\left\{(1-\beta) C_{t}^{1-\frac{1}{\partial}}+\beta\left(E_{t} U_{t+1}^{1-\gamma}\right)^{\frac{1-\frac{1}{\sigma}}{1-\gamma}}\right\}^{\frac{1}{1-\frac{1}{\sigma}}} \\
& =\left\{(1-\beta) C_{t}^{\frac{1-\gamma}{\theta}}+\beta\left(E_{t} U_{t+1}^{1-\gamma}\right)^{\frac{1}{\delta}}\right\}^{\frac{\theta}{1-\gamma}} .
\end{aligned}
$$

Here $\gamma$ is the coefficient of relative risk aversion, $\sigma$ is the elasticity of intertemporal substitution, and $\theta$ is defined, following Giovannini and Weil (1989), as $\theta=(1-\gamma) /\left(1-\frac{1}{\sigma}\right)$. Note that in general the coefficient $\theta$ can have either sign. Important special cases of the model include the case where the coefficient of relative risk aversion $\gamma$ approaches one, so that $\theta$ approaches zero; the case where the elasticity of intertemporal substitution $\sigma$ approaches one, so that $\theta$ approaches infinity; and the case where $\gamma=1 / \sigma$, so that $\theta=1$. Inspection of (3.1) shows that this last case gives the standard time-separable power utility function with relative risk aversion $\gamma$. When both $\gamma$ and $\sigma$ equal one, the objective function is the time-separable log utility function.

Epstein and Zin $(1989,1991)$ have established several important properties of this objective function. First, when consumption is chosen optimally the value function (the maximized objective function) is given by

$$
V_{t}=\max U_{t}=\left[(1-\beta)^{-\sigma} \frac{C_{t}}{W_{t}}\right]^{\frac{1}{1-\sigma}} W_{t} .
$$

The objective function (3.1) has been normalized so that the value function is linearly homogeneous in wealth (for a given consumption-wealth ratio). It is conventional to normalize the time-separable power utility function so that wealth appears in the value function raised to the power $1-\gamma$, but the normalization in (3.1) turns out to be convenient here. Naturally the normalization makes no difference to the solution of the model. ${ }^{2}$

2 The notation used here is similar to that in Epstein and Zin (1991). However their parameter $\rho$ correaponds to 1-(1/o) 
Second, the Euler equation corresponding to (3.1) can be written as

$$
1=E_{t}\left[\left\{\beta\left(\frac{C_{t+1}}{C_{t}}\right)^{-\frac{1}{\theta}}\right\}^{\theta}\left\{\frac{1}{R_{m, t+1}}\right\}^{1-\theta} R_{i, t+1}\right] .
$$

For the market portfolio itself, this takes the simpler form

$$
1=E_{t}\left[\left\{\beta\left(\frac{C_{t+1}}{C_{t}}\right)^{-\frac{1}{a}} R_{m, t+1}\right\}^{\theta}\right]
$$

These equations collapse to the familiar expressions for power utility when $\theta=1$.

When asset returns and consumption are jointly homoskedastic and lognormally distributed, the Euler equations (3.3) and (3.4) can be rewritten in log form. This rewriting can also be justified as a second-order Taylor approximation if asset returns and consumption are jointly homoskedastic. The log version of (3.4) takes the form

$$
0=\theta \log \beta-\frac{\theta}{\sigma} E_{t} \Delta c_{t+1}+\theta E_{t} r_{m, t+1}+\frac{1}{2}\left[\left(\frac{\theta}{\sigma}\right)^{2} V_{c c}+\theta^{2} V_{m m}-\frac{2 \theta^{2}}{\sigma} V_{c m}\right]
$$

Here lower case letters are again used for logs. $V_{c c}$ denotes $\operatorname{Var}_{t}\left(\Delta c_{t+1}\right)$, and other expressions of the form $V_{x y}$ are defined in analogous fashion.

Equation (3.5) implies that there is a linear relationship between expected consumption growth and the expected return on the market portfolio, with a slope coeffcient equal to the intertemporal elasticity of substitution $\sigma$. The relationship is

$$
\begin{aligned}
E_{t} \Delta c_{t+1} & =\mu_{m}+\sigma E_{t} r_{m, t+1} \\
\mu_{m} & =\sigma \log \beta+\frac{1}{2}\left[\left(\frac{\theta}{\sigma}\right) V_{c c}+\theta \sigma V_{m m}-2 \theta V_{c m}\right] \\
& =\sigma \log \beta+\frac{1}{2}\left(\frac{\theta}{\sigma}\right) \operatorname{Var}_{t}\left[\Delta c_{t+1}-\sigma r_{m, t+1}\right] .
\end{aligned}
$$

here. Their parameter $\alpha$ corresponds to $1-\gamma$ here. Thu the paramete $\theta$ here is $p / \alpha$ in their notation. Note also that there are errors in equations (10) through (12) of the'r paper. Equstion (3.2) here is a corrected version of their equadion (12). Giovannini and Weil (1989) aleo give the correct formula for the value function, although they normalize the objective function in the conventional manner for power utility. 
The intercept term $\mu_{m}$ is related to the variance of the error term in the ex post version of the linear relationship (3.6), that is, the degree of uncertainty about consumption growth relative to the return on the market. If $\theta$ is positive, a high value of this variance will cause consumers to increase the slope of their consumption growth path by postponing consumption to the future. If $\theta$ is negative, on the other hand, consumers will accelerate their consumption in response to increased uncertainty.

The log version of the general Euler equation (3.3) can be used for cross-sectional asset pricing. It takes the more complicated form

$$
\begin{aligned}
& 0=\theta \log \beta-\frac{\theta}{\sigma} E_{t} \Delta c_{t+1}+(\theta-1) E_{t} r_{m, t+1}+E_{t} r_{i, t+1} \\
& +\frac{1}{2}\left[\left(\frac{\theta}{\sigma}\right)^{2} V_{c c}+(\theta-1)^{2} V_{m m}+V_{i i}-\frac{2 \theta}{\sigma}(\theta-1) V_{c m}-\frac{2 \theta}{\sigma} V_{c i}+2(\theta-1) V_{i m}\right]
\end{aligned}
$$

When the asset under consideration is a riskfree real return $r_{f, t+1}$, this expression simplifies because some variances and covariances drop out. Subtracting the riskfree version of (3.7) from the general version and rearranging, one obtains

$$
E_{t} r_{i, t+1}-r_{f, t+1}=-\frac{V_{i i}}{2}+\theta \frac{V_{i c}}{\sigma}+(1-\theta) V_{i m}
$$

Equation (3.8) is the implication of the model emphasized by Giovannini and Weil (1989). In this expression all risk premia are constant over time because of the assumption that asset returns and consumption are homoskedastic. (3.8) says that the expected excess log return on an asset is determined by its own variance (a Jensen's Inequality effect) and by a weighted average of two covariances. The first covariance is with consumption growth divided by the intertemporal elasticity of substitution; this gets a weight of $\theta$. The second covariance is with the return on the market portfolio; this gets a weight of $1-\theta .^{3}$

Three special cases are worth noting. When the objective function is a timeseparable power utility function, the coefficient $\theta=1$ and the model collapses to the

\footnotetext{
${ }^{3}$ Chen (1991) discussea a similar result in a model with a von Neumann-Morgenatern utility function that is directly affected by the level of wealth. 
loglinear consumption CAPM of Hansen and Singleton (1983). When the coefficient of relative risk aversion $\gamma=1, \theta=0$ and a logarithmic version of the static CAPM pricing formula holds. Most important for the present paper, as the elasticity of intertemporal substitution $\sigma$ approaches one the coefficient $\theta$ goes to infinity. At the same time the variability of the consumption-wealth ratio decreases so that the covariance $V_{i c}$ approaches $V_{i m}$. It does not follow, however, that the risk premium is determined only by $V_{i m}$ in this case. Giovannini and Weil (1989) show that the convergence rates are such that asset pricing is not myopic when $\sigma=1$ unless also $\gamma=1$ (the log utility case). In the next section I give an exact expression for the risk premium in the $\sigma=1$ case.

\subsection{Substituting Out Consumption}

The loglinear Euler equations derived above can now be combined with the approximate loglinear budget constraint of section 2. Substituting (3.6) into (2.9), one obtains

$$
c_{t}-w_{t}=(1-\sigma) E_{t} \sum_{j=1}^{\infty} \rho^{j} r_{m, t+j}+\frac{\rho\left(k-\mu_{m}\right)}{1-\rho}
$$

The log consumption-wealth ratio is a constant, plus $(1-\sigma)$ times the discounted value of expected future returns on invested wealth. If $\sigma$ is less than one, the consumer is reluctant to substitute intertemporally and the income effect of higher returns dominates the substitution effect, raising today's consumption relative to wealth. If $\sigma$ is greater than one, the substitution effect dominates and the consumption-wealth ratio falls when expected returns rise. Thus equation (3.9) extends to a dynamic context the classic comparative statics results of Samuelson (1969) and Merton (1969).

Note that the coefficient of relative risk aversion $\gamma$ does not appear in (3.9) except indirectly through the parameter of linearization $\rho$. Kandel and Stambaugh (1991) have used a numerical solution method to show that $\sigma$ rather than $\gamma$ is the main determinant of the variability of expected market returns in a model with exogenous consumption and endogenous returns. Equation (3.9) provides a simple way to understand their finding. 
As discussed above, the case $\sigma=1$ is the borderline where consumption is a constant fraction of wealth. As $\sigma$ approaches one, $\theta$ approaches infinity and it is easy to see from (3.6) that the variance terms in $\mu_{m}$ must cancel if expected consumption growth is to be finite. This cancellation occurs when consumption is a constant fraction of wealth. Furthermore, by substituting the definitions of $k$ and $\rho$ into (3.9), one can show that when $\sigma=1$ the consumption-wealth ratio equals $1-\beta$, while the parameter of linearization $\rho$ equals $\beta$. Since the consumption-wealth ratio is constant when $\sigma=1$, the approximate budget constraint and asset pricing formulas of this paper hold exactly in this case if one sets $\rho=\beta$.

The approximation (3.9) can be used to restate the value function (3.2) in terms of exogenous variables. Taking logs of (3.2), one obtains

$$
v_{t}=w_{t}+\left(\frac{1}{1-\sigma}\right)\left(c_{t}-w_{t}\right)=w_{t}+E_{t} \sum_{j=1}^{\infty} \rho^{j} r_{m, t+j}
$$

The value function is determined by the level of wealth and by the discounted value of all future expected market returns, a measure of long-run investment opportunities.

(3.9) can also be used to express the innovation in consumption as a function of the return on the market and news about future returns on the market. Substituting (3.6) into (2.10), one obtains

$$
\begin{aligned}
c_{t+1}-E_{t} c_{t+1} & =r_{m, t+1}-E_{t} r_{m, t+1} \\
& +(1-\sigma)\left(E_{t+1}-E_{t}\right) \sum_{j=1}^{\infty} \rho^{j} r_{m, t+1+j}
\end{aligned}
$$

The intuition here is much the same as for equation (3.9). An unexpected return on invested wealth has a one-for-one effect on consumption, no matter what the parameters of the utility function. (This follows from the scale independence of the objective function (3.1)). An increase in expected future returns raises or lowers consumption depending on whether $\sigma$ is greater or less than one.

Equation (3.11) can be used in several different ways. First, it shows the conditions on the return process that are necessary to justify the original assumption of this section 
that consumption growth and asset returns are jointly lognormal. To a first approximation, consumption growth will be lognormal if the return on the market and revisions of expectations about future returns are jointly lognormal; thus the assumption of joint lognormality of consumption growth and asset returns can be approximately consistent with equilibrium.

Second, the equation shows when consumption will be smoother than the return on the market. There is some evidence of "mean reversion" in aggregate stock returns, that is, a negative correlation between current returns and revisions in expectations of future returns (Fama and French 1988a, Poterba and Summers 1988). According to (3.11), mean reversion reduces the variability of consumption growth if the elasticity of intertemporal substitution $\sigma$ is less than one. Mean reversion amplifies the volatility of consumption growth, however, if $\sigma$ is greater than one.

To understand this more clearly, it may be helpful to consider a simple example in which the market return follows a univariate stochastic process: $r_{m, t+1}=A(L) \epsilon_{t+1}$. Here the polynomial in the lag operator $A(L) \equiv 1+a_{1} L+a_{2} L^{2}+\ldots$, where the coefficients $a_{i}$ are the moving average coefficients of the market return process. Similarly, one can define $A(\rho) \equiv 1+a_{1} \rho+a_{2} \rho^{2}+\ldots$, the infinite sum of moving average coefficients discounted at rate $\rho$. Since $\rho$ is close to one $A(\rho)$ is approximately the sum of the moving average coefficients, a measure of the impact of today's return in. novation on long-run future wealth. In this special case $(3.11)$ can be rewritten as $c_{t+1}-E_{t} c_{t+1}=\epsilon_{t+1}+(1-\sigma)(A(\rho)-1) \epsilon_{t+1}=\sigma \epsilon_{t+1}+(1-\sigma) A(\rho) \epsilon_{t+1}$. The innovation in consumption is a weighted combination, with weights $\sigma$ and $1-\sigma$, of the current market return innovation $\epsilon_{t+1}$ and the discounted long-run impact of the return innovation $A(\rho) \epsilon_{t+1}$. Mean reversion in the market return makes $A(\rho)<1$, which reduces the variability in consumption if $\dot{\sigma}<1$.

Third, equation (3.11) can be used to clarify the interpretation of the intercept coefficient $\mu_{m}$ in the equation relating consumption growth and the expected return on the market. Substituting (3.11) into (3.6), $\mu_{m}$ can be written as

$$
\begin{aligned}
\mu_{m}= & \sigma \log \beta+\left(\frac{1}{2}\right)(1-\sigma)^{2}\left(\frac{\theta}{\sigma}\right) \operatorname{Var}_{t}\left[\left(E_{t+1}-E_{t}\right) \sum_{j=0}^{\infty} \rho^{j} r_{m, t+1+j}\right] \\
= & \sigma \log \beta+\left(\frac{1}{2}\right)(1-\sigma)^{2}\left(\frac{\theta}{\sigma}\right) \operatorname{Var}_{t} v_{t+1} . \\
& -13-
\end{aligned}
$$


The summation in (3.12) runs from zero to infinity, since the uncertainty that affects $\mu_{m}$ includes both the variance of this period's market return and the variance of news about future market returns. The second equality in (3.12) follows from the solution for the value function (3.10). (3.12) shows that the conditional variance of expected long-run investment opportunities (equivalently, the conditional variance of the value function) is the correct measure of risk in this model. As discussed above, the sign of $\theta$ determines whether consumers will postpone or accelerate consumption in response to this risk.

Finally, equation (3.11) implies that the covariance of any asset return with consumption growth can be rewritten in terms of covariances with the return on the market and revisions in expectations of future returns on the market. ${ }^{4}$ The covariance satisfies

$$
\operatorname{Cov}_{t}\left(r_{i, t+1}, \Delta c_{t+1}\right) \equiv V_{i c}=V_{i m}+(1-\sigma) V_{i h}
$$

where

$$
V_{i h} \equiv \operatorname{Cov}_{t}\left(r_{i, t+1},\left(E_{t+1}-E_{t}\right) \sum_{j=1}^{\infty} \rho^{j} r_{m, t+1+j}\right)
$$

$V_{i h}$ is defined to be the covariance of the return on asset $i$ with good ncws about future returns on the market, i.e. upward revisions in expected future returns. ${ }^{5}$

Substituting (3.13) into (3.8) and using the definition of $\theta$ in terms of the underlying parameters $\sigma$ and $\gamma$, I obtain a cross-sectional asset pricing formula that makes no reference to consumption:

$$
E_{t} r_{i, t+1}-r_{f, t+1}=-\frac{V_{i i}}{2}+\gamma V_{i m}+(\gamma-1) V_{i h}
$$

Equation (3.15) has several striking features. First, assets can be priced without

\footnotetext{
'Equally, (3.11) could be used to rewrite the covariance with the market in terms of covariances with consumption and revisions in expectations of future investment opport unities. The contribution of (3.11) is to show that only two of these three covariances need be measured accuratcly in order to have a testable asset pricing theory.

5 The notation $V_{i s}$ is chosen to accord with Campbell (1991a). It recallo the standard terminology of "hedge portfolios" (e.g. Ingersoll 1987). 
direct reference to their covariance with consumption growth, using instead their covariances with the return on invested wealth and with news about future returns on invested wealth. This is a discrete-time analogue of Merton's (1973) continuous-time model in which assets are priced using their covariances with certain "hedge portfolios" that index changes in the investment opportunity set.

Second, the only parameter of the utility function that enters (3.15) is the coefficient of relative risk aversion $\gamma$. The elasticity of intertemporal substitution $\sigma$ does not appear once consumption has been substituted out of the model. This is in striking contrast with the important role played by $\sigma$ in the consumption-based Euler equation (3.8). Intuitively, this result comes from the fact that $\sigma$ plays two roles in the theory. A low value of $\sigma$ reduces anticipated fluctuations in consumption (equation (3.6)), but it also increases the risk premium required to compensate for any contribution to these fluctuations (equation (3.8)). These offsetting effects lead $\sigma$ to cancel out of the assetbased pricing equation (3.15). Kocherlakota (1990) and Svensson (1989) have already shown that $\sigma$ is irrelevant for asset pricing when asset returns are independently and identically distributed over time. This is not surprising, since with i.i.d. returns there is no interesting role for intertemporal substitution in consumption. The present result is approximate but is much stronger, since it holds in a world with changing conditional mean asset returns.

Third, equation (3.15) expresses the risk premium (net of the Jensen's inequality effect) as a weighted sum of two terms. The first term is the asset's covariance with the market portfolio; the weight on this term is the coefficient of relative risk aversion $\gamma$. The second term is the asset's covariance with news about future returns on the market; this receives a weight of $\gamma-1$. When $\gamma$ is less than one, assets that do well when there is good news about future returns on the market have lower mean returns, but when $\gamma$ is greater than one, such assets have higher mean returns. The intuitive explanation is that such assets are desirable because they enable the consumer to profit from improved investment opportunities, but undesirable because they reduce the consumer's ability to hedge against a deterioration in investment opportunities. When $\gamma<1$ the former effect dominates, and consumers are willing to accept a lower return in order to hold assets that pay off when wealth is most productive. When $\gamma>1$ the latter effect dominates, and consumers require a higher return to hold such assets.

There are several possible circumstances under which assets can be priced using only their covariances with the return on the market portfolio, as in the logarithmic 
version of the static CAPM. These cases have been discussed in the literature on intertemporal asset pricing, but equation (3.15) makes it particularly easy to understand them. First, if the coefficient of relative risk aversion $\gamma=1$, then the opposing effects of covariance with investment opportunities cancel out so that only covariance with the market return is relevant for asset pricing. Giovannini and Weil (1989) emphasize this result, and it has been long understood for the special case of log utility, where not only $\gamma=1$, but also $\sigma=1$. Second, if the investment opportunity set is constant, then $V_{\text {ih }}$ is zero for all assets so again assets can be priced using only their covariances with the market return. Fama (1970) and Merton $(1969,1971)$ stress this result. Third, if the return on the market follows a univariate stochastic process, then news about future returns is perfectly correlated with the current return. Using the lag operator notation introduced above, in this case $V_{i h}=(A(\rho)-1) V_{i m}$ for all assets $i$, and the risk premium (ignoring the Jensen's inequality term) is $[\gamma+(\gamma-1)(A(\rho)-1)] V_{i m}$. Giovannini and Weil (1989) and Merton (1990, Chapter 16) present results of this type in discrete time and continuous time respectively.

One obvious application of the formula (3.15) is to the equity premium, the risk premium on the market itself. When the market return is serially uncorrelated, the equity premium net of the Jensen's Inequality term is just $\gamma V_{m m}$, and the coefficient of relative risk aversion can be estimated in the manner of Friend and Blume (1975) by taking the ratio of the equity premium to the variance of the market return. However this procedure can be seriously misleading if the market return is serially correlated. With a univariate market return process, for example, the equity premium net of the Jensen's Inequality term is $[\gamma+(\gamma-1)(A(\rho)-1)] V_{m m}$. Mean reversion in stock returns (the case $A(\rho)<1$ ) reduces the equity premium when $\gamma>1$ but increases it when $\gamma<1$. The Friend and Blume estimate of risk aversion will be off by $(\gamma-1)(A(\rho)-1)$. This error can be substantial, particularly if $\gamma$ is very large as suggested by Kandel and Stambaugh (1991) among others. Black (1990) also emphasizes that mean reversion can affect the relation between short-run market volatility and the equity premium.

\subsection{The Term Structure of Real Interest Rates}

Real bonds, which make fixed payments of consumption goods, play a special role in asset pricing theory because they have no payoff uncertainty. The only uncertainty in their return comes from changes in the real interest rates used to discount their payoffs. 
In this section I show that in a lognormal homoskedastic model, the unexpected return on a real consol bond is approximately equal to minus the news about future returns on invested wealth. This means that the covariance with good news about future returns can also be written as minus the covariance with the return on a real consol.

Let $p_{b t}$ denote the log price at time $t$ of a real consol bond paying 1 unit of the consumption good each period, with no maturity date. The log return on this bond is

$$
r_{b, t+1} \equiv \log \left(1+\exp \left(p_{b, t+1}\right)\right)-p_{b t}
$$

Linearizing this expression with a first-order Taylor expansion in the manner of section 2 , one obtains the approximation

$$
r_{b, t+1} \approx k_{b}+\rho_{b} p_{b, t+1}-p_{b t},
$$

where $\rho_{b}$ is the reciprocal of the average gross, simple return on the consol: $\rho_{b}=1 / \bar{R}_{b}$.

This implies that $p_{b t}$ is determined by the discounted value of expected future returns on the bond, or equivalently by the discounted value of expected future returns on invested wealth (in the homoskedastic model these are the same, up to a constant risk premium):

$$
p_{b t}=E_{t} \sum_{j=1}^{\infty} \rho_{b}^{j} r_{m, t+j}+k^{*}
$$

for some constant $k^{*}$. Substituting (3.18) back into (3.17), one obtains

$$
r_{b, t+1}-E_{t} r_{b, t+1}=-\left(E_{t+1}-E_{t}\right) \sum_{j=1}^{\infty} \rho_{b}^{j} r_{m, t+1+j}
$$

In general $\rho_{b}$ does not equal the parameter of linearization for the intertemporal budget constraint, $\rho$. However the difference is likely to be small, and it will have 
little effect on a discounted value like the right hand side of (3.19) if news about future returns on the market dies out fairly rapidly. Thus

$$
\operatorname{Cov}_{t}\left(r_{i, t+1}, r_{b, t+1}\right) \equiv V_{i b} \approx-V_{i h}
$$

and the asset pricing equation (3.15) can be rewritten as

$$
E_{t} r_{i, t+1}-r_{f, t+1}=-\frac{V_{i i}}{2}+\gamma V_{i m}+(1-\gamma) V_{i b}
$$

Equation (3.21) says that the expected log return on any asset is determined by its own variance, and by a weighted average of its covariances with the market portfolio and with a real consol bond. The weights on the market and the consol are $\gamma$ and $1-\gamma$ respectively, where as before $\gamma$ is the coefficient of relative risk aversion.

Equation (3.21) is reminiscent of the formula in Merton (1973) that expresses the expected excess return on any asset as a linear function of its covariances with the market and with the return on an asset perfectly correlated with changes in shortterm interest rates (loosely, a long-term bond) ${ }^{6}$ However the present model differs from Merton's in two important respects. First, Merton's result depends on the assumption that all changes in investment opportunities are summarized by the change in a single state variable, the instantaneous interest rate. Here, the short-term interest rate summarizes the current investment opportunity set (because all asset returns move in parallel in the homoskedastic model), but it does not summarize all changes in investment opportunities (because there can be many sotrces of news about future returns). Another way to see the difference is to note that in Merton's model long-term bond returns and changes in short-term rates are perfectly correlated instantaneously, whereas this need not be the case in the present model. ${ }^{7}$ Second, Merton's model gives the prices of the two sources of risk only in terms of the derivatives of the consumer's value function, which are endogenous to the model. Here, the risk prices are explicitly determined by the primitive parameters of the consumer's utility function.

\footnotetext{
This is equation (32) of Merton (1973), reprinted as equation (15.32) in Merton (1990). Bossaerts and Green (1989), Breeden (1986), and Rubinstein (1981) also emphasize the importance of real bonds in asset pricing.

${ }^{7}$ In another respect, however, Merton's model is more general because it allows variances to depend on the interest rate. In the next section I allow for changing variances in the present framework. 


\subsection{A Vector Autoregressive Factor Pricing Model}

The results of the previous section would be useful for empirical work if real consol returns were observable. Unfortunately such assets do not exist; the closest equivalent may be finite-maturity index bonds in the United Kingdom, and even these have been actively traded only in recent years. Another approach is needed to derive testable implications of the basic asset pricing equation (3.15).

Here I adapt the vector autoregressive approach of Campbell (1991a). ${ }^{8}$ I assume that the return on the market can be written as the first element of a $K$-element state vector $z_{t+1}$. The other elements are variables that are known to the market by the end of period $t+1$, and are relevant for forecasting future returns on the market. I assume that the vector $z_{t+1}$ follows a first-order vector autoregression (VAR):

$$
z_{t+1}=A z_{t}+\epsilon_{t+1}
$$

The assumption that the VAR is first-order is not restrictive, since a higher-order VAR can always be stacked into first-order (companion) form in the manner discussed by Campbell and Shiller (1988a). The matrix $A$ is known as the companion matrix of the VAR. ${ }^{9}$

Next I define a $K$-element vector $e 1$, whose first element is one and whose other elements are all zero. This vector picks out the real stock return $r_{m, t+1}$ from the vector $z_{t+1}: r_{m, t+1}=e 1^{\prime} z_{t+1}$, and $r_{m, t+1}-E_{t} r_{m, t+1}=e 1^{\prime} \epsilon_{t+1}$. The first-order VAR generates simple multi-period forecasts of future returns:

$$
E_{t} r_{m, t+1+j}=e 1^{l} A^{j+1} z_{t}
$$

It follows that the discounted sum of revisions in forecast returns can be written as

\footnotetext{
Campbell uses this approach to decompose the overall market return into news about dividends and news about fut ure market returne. In the present homoskedadic context the latter component is just the return on a real consol, as diecussed above. Equation (3.15) eays that the dividend news component of the market return has risk price $\gamma_{1}$ while the return news component hal riak price $1-\gamma$.

As is well known, VAR systems can be normalized in different ways. For example, the variablea in the state vector can be orthogonalized so that the variance-covariance matrix of the error vector $e$ is diagonal. The results given below hold for any observationally equivalent normaliestion of the VAR aystem.
} 


$$
\begin{aligned}
\left(E_{t+1}-E_{t}\right) \sum_{j=1}^{\infty} \rho^{j} r_{m, t+1+j} & =e 1^{\prime} \sum_{j=1}^{\infty} \rho^{j} A^{j} \epsilon_{t+1} \\
& =e 1^{\prime} \rho A(I-\rho A)^{-1} \epsilon_{t+1} \\
& =\lambda^{\prime} \epsilon_{t+1},
\end{aligned}
$$

where $\lambda^{\prime}$ is defined to equal $e l^{\prime} \rho A(I-\rho A)^{-1}$, a nonlinear function of the VAR coefficients. The elements of the vector $\lambda$ measure the importance of each state variable in forecasting future returns on the market. If a particular element $\lambda_{k}$ is large and positive, then a shock to variable $k$ is an important piece of good news about future investment opportunities.

I now define

$$
V_{i k} \equiv \operatorname{Cov}_{t}\left(r_{i, t+1}, \epsilon_{k, t+1}\right)
$$

where $\epsilon_{k, t+1}$ is the $k$ 'th element of $\epsilon_{t+1}$. Since the first element of the state vector is the return on the market, $V_{i 1}=V_{i m}$. Then equations (3.24), (3.25), and (3.15) imply that

$$
E_{t} r_{i, t+1}-r_{f, t+1}=-\frac{V_{i i}}{2}+\gamma V_{i 1}+(\gamma-1) \sum_{k=1}^{K} \lambda_{k} V_{i k}
$$

where $\lambda_{k}$ is the $k$ 'th element of $\lambda$. This is a standard $K$-factor asset pricing model, and its general form could be derived in any number of ways: perhaps most straightforwardly by using the Arbitrage Pricing Theory of Ross (1976).

The contribution of the intertemporal optimization problem is a set of restrictions on the risk prices of the factors. The first factor (the return on the market) has a risk price of $\gamma+(\gamma-1) \lambda_{1}$. A positive value of $\lambda_{1}$ means that the return on the market is positively correlated with revisions in expected future returns, while a negative value 
of $\lambda_{1}$ means that the market return is "mean reverting". These serial correlation properties of the market return affect the risk price of the market factor; if the market is mean reverting, for example, its risk price is reduced if $\gamma$ is greater than one.

The other factors in this model have risk prices of $(\gamma-1) \lambda_{k}$. Factors here are variables that help to forecast the return on the market, and their risk prices are proportional to their forecasting importance as measured by the elements of the vector $\lambda$. If a particular variable has a positive value of $\lambda_{k}$, this means that innovations in that variable are associated with good news about future investment opportunities. Following the analysis in section 3.2 , such a variable will have a negative risk price if the coefficient of relative risk aversion $\gamma$ is less than one, and a positive risk price if the coefficient of relative risk aversion is greater than one.

Thus the intertemporal model suggests that priced factors should be found not by running a factor analysis on the covariance matrix of returns (Roll and Ross 1980), nor by selecting important macroeconomic variables (Chen, Roll, and Ross 1986). Instead, variables that have been shown to forecast stock market returns should be used in cross-sectional asset pricing studies. Recent empirical work suggests that dividend yields, interest rates and other financial variables are likely to be important (Campbell 1987,1991a, Campbell and Shiller 1988a,b, Fama and Schwert 1977, Fama and French 1988b,1989, Keim and Stambaugh 1986). 


\section{Intertemporal Asset Pricing with Changing Variances}

In this section I relax the unrealistic assumption of the previous section that all variances and covariances of log asset returns and consumption are constant through time. Relaxing this assumption has no effect on the log-linearization of the budget constraint in section 2 or the formulation of the intertemporal optimization problem in section 3.1. What it does do is change the log form of the Euler equations for this problem. If asset returns and consumption are jointly lognormal, but heteroskedastic rather than homoskedastic, equations (3.5) through (3.8) hold with time $t$ subscripts on the variances and covariances; constants of the form $V_{x y}$ become variables of the form $V_{x y, t}$. These modified log Euler equations also hold as second-order Taylor approximations if asset returns and consumption are not lognormal.

The more general form of equation (3.6) is

$$
\begin{aligned}
E_{t} \Delta c_{t+1} & =\mu_{m, t}+\sigma E_{t} r_{m, t+1} \\
\mu_{m, t} & =\sigma \log \beta+\frac{1}{2}\left[\left(\frac{\theta}{\sigma}\right) V_{c c, t}+\theta \sigma V_{m m, t}-2 \theta V_{c m, t}\right] \\
& =\sigma \log \beta+\frac{1}{2}\left(\frac{\theta}{\sigma}\right) \operatorname{Var}_{t}\left[\Delta c_{t+1}-\sigma r_{m, t+1}\right]
\end{aligned}
$$

The intercept $\mu_{m, t}$, which was previously constant, now changes over time with the variance of consumption growth relative to the market return. This means that when (4.1) is substituted into the approximate loglinear budget constraint (2.9), extra terms appear in the formulas for the log consumption-wealth ratio and the innovation in log consumption. Equation (3.11) becomes

$$
\begin{aligned}
c_{t+1}-E_{t} c_{t+1} & =r_{m, t+1}-E_{t} r_{m, t+1} \\
& +(1-\sigma)\left(E_{t+1}-E_{t}\right) \sum_{j=1}^{\infty} \rho^{j} r_{m, t+1+j} \\
& -\left(E_{t+1}-E_{t}\right) \sum_{j=1}^{\infty} \rho^{j} \mu_{m, t+j}
\end{aligned}
$$


The new term in equation (4.2) reflects the influence of changing risk on saving. The variable $\mu_{m, t}$ is proportional to the conditional variance of consumption growth less $\sigma$ times the return on invested wealth. As this changes, consumers may be induced to accelerate or postpone consumption. The difficulty is that equation (4.2), unlike the homoskedastic equivalent (3.11), still makes reference to consumption growth on the right hand side through the variable $\mu_{m, t}$ which is a function of the second moments of consumption. Thus equation (4.2) cannot be used to substitute consumption growth out of the intertemporal asset pricing model without further assumptions.

There are, however, several special cases in which consumption can be substituted out of the model with changing variances. First, if the coefficient of relative risk aversion $\gamma=1$, then $\theta=0$ and $\mu_{m}$ remains constant even in the heteroskedastic case. Thus when $\gamma=1$ a logarithmic version of the static CAPM holds with changing conditional variances. Second, if the elasticity of intertemporal substitution $\sigma=1, \theta$ is infinite and the conditional variance in (4.1) must be zero. In this case the intertemporal asset pricing formula (3.15) continues to hold with time subscripts on the conditional variances. Presumably this formula is a good approximation if $\sigma$ is not too far from one or if conditional variances are not highly variable or persistent. Third, the asset pricing formula (3.15) describes any asset returns that are uncorrelated with revisions in expectations of future intercepts $\mu_{m, t+j}$. Restoy (1991), building on the analysis of this paper, has shown that (3.15) describes the equity premium if the variance of market returns follows a GARCH process that is uncorrelated with the return on the market.

A final special case assumes, in the spirit of Cox, Ingersoll, and Ross (1985), that the intercept $\mu_{m, t}$ is a linear function of the expected return on the market. Suppose that

$$
\mu_{m, t}=\mu_{0}+\psi E_{t} r_{m, t+1}
$$

for some coefficient $\psi .^{10}$ Then the innovation in consumption can be rewritten as

\footnotetext{
${ }^{10}$ This condition is slightly problematic in a discrete time model, because strictly speaking it is inconsistent with the nomality of conditional expected returs on the market and the positivity of the variances defining $1 \mathrm{~m}$. Whether this is $\Delta$ serious problem will depend on the parameter values of the model. 


$$
\begin{aligned}
c_{t+1}-E_{t} c_{t+1} & =r_{m, t+1}-E_{t} r_{m, t+1} \\
& +(1-\sigma-\psi)\left(E_{t+1}-E_{t}\right) \sum_{j=1}^{\infty} \rho^{j} r_{m, t+1+j}
\end{aligned}
$$

It follows that the covariance of any asset return with consumption growth can be written as

$$
\operatorname{Cov}_{t}\left(r_{i, t+1}, \Delta c_{t+1}\right) \equiv V_{i c, t}=V_{i m, t}-(1-\sigma-\psi) V_{i h, t}
$$

and the expected excess return on any asset is given by

$$
E_{t} r_{i, t+1}-r_{S, t+1}=-\frac{V_{i i, t}}{2}+\gamma V_{i m, t}+\left[(\gamma-1)-\frac{\theta \psi}{\sigma}\right] V_{i h, t}
$$

This formula for the risk premium is the same as before, with the addition of a term involving the sensitivity of the consumption intercept to the expected return on the market, $\psi$. This term may be positive or negative in general, and it is interpreted as follows. A $1 \%$ increase in the expected return on the market lowers consumption by $\psi \%$ through the precautionary saving channel. The market price of consumption risk is $\theta / \sigma$, so the market price of investment opportunity set risk includes a term $-\theta \psi / \sigma$.

It is important to find conditions on the exogenous process for asset returns that justify the assumption on $\mu_{m, t}$ (4.3). One can show that $\mu_{m, t}$ will satisfy (4.3) if the variances and covariance of the return on the market and news about future returns on the market are linear functions of the expected return on the market. In other words, if for $\{x, y\}=\{m, h\}$ we have that

$$
V_{x y, t}=V_{x y}^{0}+V_{x y}^{1} E_{t} r_{m, t+1}
$$

then (4.3) is satisfied. ${ }^{11}$ This assumption on returns is a discrete-time analogue of the assumption used in Cox, Ingersoll, and Ross (1985).

\footnotetext{
${ }^{21}$ However some value of the slope coefficienta in (4.7) may give s complex rather than real wolution for $\psi$.
} 
In this model the variance-covariance matrix of the return on the market and news about future returns on the market changes with one underlying variable, the expected return on the market. This means that the expected excess return on the market, as given by equation (4.6) for asset $i=m$, can be written as a linear function of the conditional variance of the return on the market. Substituting (4.7) into (4.6) for asset $i=m$, one obtains

$$
\begin{aligned}
E_{t} r_{m, t+1}-r_{f, t+1} & =\beta_{0}+\beta_{1} V_{m m, t} \\
\beta_{0} & =\left(\gamma-1-\frac{\theta \psi}{\sigma}\right)\left(V_{m h}^{0}-\frac{V_{m h}^{1} V_{m m}^{0}}{V_{m m}^{1}}\right) \\
\beta_{1} & =\gamma-\frac{1}{2}+\left(\gamma-1-\frac{\theta \psi}{\sigma}\right) \frac{V_{m h}^{1}}{V_{m m}^{1}} .
\end{aligned}
$$

This result sheds new light on the large empirical literature that estimates a linear relation between the conditional mean and variance of the return on the aggregate stock market (for example Bollerslev, Engle, and Wooldridge 1988, French, Schwert, and Stambaugh 1987, and Merton 1980). It is sometimes argued that linearity will hold in a fully specified intertemporal asset pricing model only if agents have log utility. The model of this section provides a counter-example to this claim. It is important to note, however, that the market price of conditional volatility, given by the coefficient $\beta_{1}$ in equation (4.8), does not generally equal the coefficient of relative risk aversion $\gamma$. 


\section{How Accurate is the Log-Linear Approximation?}

Earlier sections of the paper. have stated some strikingly simple results about the determination of expected asset returns. These results are based on a log-linear approximation to the intertemporal budget constraint that will be accurate when the log consumption-wealth ratio is "not too" variable. In this section I try to characterize more precisely the circumstances under which the approximation works well. To do this, I assume a specific market return process and consider alternative parameter values for the representative consumer's objective function. For each set of parameter values I calculate optimal consumption functions numerically and compare them with the approximate analytical solutions derived above.

To reduce the complexity of the problem, I first specialize the model of section 3 to a simple example discussed in Campbell (1991a). In this example, the expected return on the market portfolio follows a univariate $\operatorname{AR}(1)$ process with coefficient $\phi$, while the realized return is the expected return plus a white noise error. This should not be confused with the special case discussed in previous sections in which the market return itself is a univariate process. The model considered here is

$$
\begin{aligned}
r_{m, t+1} & =E_{t} r_{m, t+1}+\epsilon_{1, t+1} \\
E_{t+1} r_{m, t+2} & =\phi E_{t} r_{m, t+1}+\epsilon_{2, t+1} .
\end{aligned}
$$

The free parameters of this model are the coefficient $\phi$ and the second moments $V_{11}, V_{12}$, and $V_{22}$.

The next step is to pick reasonable values for these parameters. Campbell (1991a) estimates persistence measures for expected returns using CRSP monthly data on valueweighted U.S. stock returns over the period 1927-1988. The persistence measures are estimated using a VAR system of the type discussed in section 3.4, rather than the simple AR(1) model (5.1). However it is straightforward to calculate the AR(1) parameter that would correspond to any VAR persistence measure. Campbell's estimates imply $\phi=0.79$ over the full 1927-1988 sample period, and a similar value of $\phi=0.83$ in the postwar 1952-1988 sample period. Thus $\phi=0.8$ is a realistic benchmark value to use in the AR(1) model. This value of $\phi$ implies a halfife for expected return shocks of 
just over three months.

Once one has a value of $\phi$, the innovation variance of expected returns can be found by using the fact that the variance of expected returns $\operatorname{Var}\left(E_{t} r_{m, t+1}\right)=V_{22} /\left(1-\phi^{2}\right)$. The variance of expected returns is given by the variance of the fitted value in a regression of returns on the relevant information, or equivalently by the overall variance of returns and the $\mathrm{R}^{2}$ statistic from the regression. Campbell's (1991a) estimates imply that $V_{11}=(0.0563)^{2}$ and $V_{22}=(0.0063)^{2}$ in the $1927-1988$ sample period. The implied standard deviation for monthly expected returns, when $\phi=0.8$, is just over $1 \%$ at a monthly rate. This compares to an overall standard deviation of the monthly ex post return of $5.7 \%$, implying a monthly $R^{2}$ statistic of just over $3 \%$. Finally, the correlation between innovations in expected returns and realized returns is estimated to be about -0.8 , and I pick this value for the example here. These estimates imply substantial variability in expected returns, and also considerable mean reversion in the market return process.

Approximate loglinear consumption rules are straightforward to derive in this example. The log consumption-wealth ratio is

$$
c_{i}-w_{t}=\frac{(1-\sigma) \rho}{1-\rho \phi} E_{t} r_{m, t+1}+\frac{\rho\left(k-\mu_{m}\right)}{1-\rho}
$$

while the consumption growth rate is

$$
E_{t} \Delta c_{t+1}=\mu_{m}+\sigma E_{t} r_{m, t+1}+\epsilon_{1, t+1}+\frac{(1-\sigma) \rho}{1-\rho \phi} \epsilon_{2, t+1}
$$

Note that negative correlation between $\epsilon_{1, t+1}$ and $\epsilon_{2, t+1}$ makes consumption smoother if $\sigma<1$ but more volatile if $\sigma>1$.

The exact optimal consumption function can only be calculated numerically. Building on the work of Tauchen and Hussey (1991), I use Gaussian quadrature to approximate the normal distribution of the expected return in (5.1) by a nine-state Markov process. I then use an iterative procedure to calculate the optimal consumption-wealth ratio in each state and the corresponding value function. Full details are given in Campbell and Koo (1992); here I simply summarize the results.

Table 1 shows the mean value function for a wealth level of 100 (that is, the mean 
value function as a percentage of wealth), calculated numerically for a grid of six values of $\sigma$ and six values of $\gamma . \sigma$ is set equal to $0.05,0.50,1.00,2.00,3.00$, and 4.00 , while $\gamma$ is $0.00,0.50,1.00,2.00,3.00$, and 4.00. The smallest value of $\sigma$ is 0.05 rather than 0.00 because the program encounters some numerical difficulties when $\sigma$ is extremely small. All the results reported assume that the mean market return is $6.5 \%$ at an annual rate and that the discount factor $\beta$ is the twelfth root of 0.94 , giving the monthly equivalent of a $6 \%$ annual discount rate.

Table 1 also shows the percentage losses in the mean objective function that result from using the loglinear consumption rule (3.9). Since the objective function has been normalized to be linear in wealth, these losses have the same units as reductions in wealth. The first number in parentheses is the percentage utility loss when $\rho$ is obtained from (2.5) with the true optimal value of the mean log consumption-wealth ratio. The second number in parentheses is the percentage utility loss when $\rho$ is set equal to $\beta$, its value for the $\sigma=1$ case. The first procedure gives a more accurate approximation, but it requires knowledge of the true mean log consumption-wealth ratio. The second procedure is less accurate but more easily implementable in practice.

As one would expect, the utility losses from using loglinear consumption rules increase as $\sigma$ moves further from unity. The losses are zero when $\sigma=1$, for then the approximations are exact. When $\sigma=0.5$ or 2.00 , the approximate consumption functions cost less than $0.01 \%$ of wealth unless $\gamma$ is at its highest value of 4.00 . When $\sigma=0.05,3.00$, or 4.00 , the approximate consumption function with the correct $\rho$ still costs no more than $0.01 \%$ of wealth, but the approximate consumption function setting $\rho=\beta$ is noticeably less accurate. As an extreme case, when both $\sigma$ and $\gamma$ are at their maximum values of 4.00 , this approximation costs $1.2 \%$ of wealth.

Table 2 shows mean optimal consumption as a percentage of wealth. Since $\beta$ and the expected return process are fixed, the mean consumption-wealth ratio varies considerably as the parameters $\gamma$ and $\sigma$ vary. The smallest value in the table is $0.237 \%$ (2.84\% at an annual rate) when $\sigma=4.00$ and $\gamma=0.00$. The largest value is $1.05 \%$ (12.6\% at an annual rate) when $\sigma=4.00$ and $\gamma=4.00$. The table also reports the differences between the exact and approximate mean consumption-wealth ratios, expressed as percentages of the exact mean consumption-wealth ratio. These differences are again zero when $\sigma=1$, but they increase quite rapidly as $\sigma$ moves away from one. When the approximation uses the true $\rho$, the error is $0.05 \%$ to $0.25 \%$ of the exact mean consumption-wealth ratio when $\sigma=0.05$ or 2.00 , increasing to almost $1.5 \%$ of the exact 
mean consumption-wealth ratio when $\sigma=4.00$. When the approximation uses $\rho=\beta$, the errors can be many times larger.

If one is interested in the dynamic behavior of consumption and its implications for asset pricing, errors in the mean consumption-wealth ratio are relatively unimportant. What is important is to approximate accurately the variation of the consumptionwealth ratio and the consumption growth rate around their means. Table 3 gives the standard deviation of the optimal log consumption-wealth ratio, along with the percentage errors of the two approximations. The log ratio is used because this is approximately normally distributed. The table shows that as $\sigma$ approaches one, the approximation error for the log standard deviation goes to zero at almost the same rate as the log standard deviation itself. Thus in percentage terms the approximation error is almost constant and small at about $0.75 \%$ of the true standard deviation. Table 4 reports the standard deviation of the optimal log consumption growth rate, again with the percentage errors of the two approximations. The consumption-smoothing effect of mean reversion when $\sigma$ is low is clearly visible in this table. The approximations tend to understate the variability of $\log$ consumption growth when $\sigma$ is low and to overstate the variability when $\sigma$ is high. However the errors are quite small, never much above $0.5 \%$ of the true standard deviation when the correct. value of $\rho$ is used. The approximation setting $\rho=\beta$ should be used more cautiously, as its maximum error is four times greater than the the approximation error using the true $\rho$.

These results are encouraging for two reasons. First, they are obtained using a model in which the expected return on the market is highly variable. Less extreme variability in the expected return process would increase approximation accuracy by reducing the variability of the optimal consumption-wealth ratio. Second, a number of authors (Campbell and Mankiw 1989, Giovannini and Weil 1989, Hall 1988, Kandel and Stambaugh 1991) have argued from direct evidence on consumption and asset price behavior that $\sigma$ is more likely to be very small than very large. Tables 3 and 4 show that a loglinear approximation to the intertemporal budget constraint is workably accurate when $\sigma$ is close to zero, even if the true value of $\rho$ is unknown. 


\section{Conclusions.}

In this paper 1 have argued that intertemporal asset pricing theory has become unnecessarily tangled in complications caused by the nonlinearity of the intertemporal budget constraint. I have proposed a log-linear approximation to the constraint as a way to cut this Gordian knot. In a simple example calibrated to U.S. stock return data, the approximation seems to be workably accurate when the elasticity of intertemporal substitution is less than about 3 .

I assume that asset returns and news about future returns are jointly lognormal and homoskedastic, and that there is a representative agent who maximizes the objective function proposed by Epstein and Zin $(1989,1990)$ and Weil (1987). This objective function has many of the appealing features of the time-separable power utility function, but it separates the elasticity of intertemporal substitution $\sigma$ from the coefficient of relative risk aversion $\gamma$ rather than forcing these parameters to be reciprocals of one another as in the power utility case. The log-linear approximation to the budget constraint then yields some simple propositions about consumption behavior and intertemporal asset pricing.

1. The $\log$ consumption-wealth ratio equals a constant, plus $(1-\sigma)$ times the discounted value of all future expected returns on invested wealth. The innovation to $\log$ consumption equals the innovation to the log return on the market, plus $(1-\sigma)$ times the revision in the discounted value of future market returns. As one would expect, the coefficient $\sigma$ rather than $\gamma$ governs the response of consumption to changing expected asset returns.

2. The expected excess log return on any asset over the riskfree return is the sum of three terms. The first term is minus one half the own variance of the log asset return, a Jensen's Inequality effect. The second term is $\gamma$ times the covariance of the asset return with the return on the market, as in a logarithmic version of the static CAPM. The third term is $1-\gamma$ times the covariance of the asset return with news about future returns on the market. As one would expect, the coefficient $\gamma$ rather than $\sigma$ determines the size and sign of asset risk premia.

3. In the homoskedastic model, the log return on a real consol bond is approximately equal to minus the news about future returns on the market. Thus the expected excess return on any asset, net of the Jensen's Inequality effect, can also be written as a weighted average of the asset's covariance with the market and with the consol. 
The weights are $\gamma$ and $1-\gamma$ respectively.

4. If the return on the market can be written as one element of a state vector that follows a homoskedastic vector autoregression (VAR), then the intertemporal theory delivers a set of restrictions on the risk prices of a factor asset pricing model. The factors are variables that are relevant for forecasting the market and hence enter the VAR state vector. Their risk prices are proportional to their importance in forecasting the discounted value of future returns on the market.

5. The results above can be generalized to allow a restricted form of heteroskedasticity in asset returns. If the conditional variance-covariance matrix of the return on the market and news about future returns on the market is linear in the expected return on the market, then the asset pricing model goes through as before, except that the price of covariance with news about future returns is no longer equal to $1-\gamma$. With this form of heteroskedasticity, the expected excess return on the market is linear in the conditional variance of the return on the market, as commonly assumed in empirical work. The homoskedastic results also generalize straightforwardly if $\sigma$ or $\gamma$ are sufficiently close to one.

These results have pedagogic value as a simple way to understand the vast and complicated literature on intertemporal asset pricing. They also raise the hope that this subject can be brought into a closer relationship with the equally large body of work on cross-sectional factor asset pricing models. An important topic for future research will be to test the restrictions placed by the approximate intertemporal model on cross-sectional factor risk prices.

The main difficulty in conducting such a test is that, as emphasized by Roll (1977), the return on the market portfolio is imperfectly measured. If neither consumption data nor market return data are adequate, then it may be necessary to develop a more explicit general equilibrium model in which macroeconomic variables help to identify the returns on physical and human capital. The loglinear approximation of this paper has already been used to solve real business cycle models by Campbell (1991b), Christiano (1988), King, Plosser, and Rebelo (1987) and others, and the application of macroeconomic models to asset pricing promises to be another active area of research. 


\section{Bibliography}

Black, Fischer, 1990, "Mean Reversion and Consumption Smoothing", Review of Fi. nancial Studies 3, 107-114.

Bollerslev, Tim, Robert F. Engle, and Jeffrey Wooldridge, 1988, "A Capital Asset Pricing Model with Time Varying Covariances", Journal of Political Economy 96, 116-131.

Bossaerts, Peter and Richard C. Green, 1989, "A General Equilibrium Model of Changing Risk Premia: Theory and Tests", Review of Financial Studies 2, 467-493.

Breeden, Douglas, 1979, "An Intertemporal Asset Pricing Model with Stochastic Consumption and Investment", Journal of Financial Economics 7, 265-296.

Breeden, Douglas, 1986, "Consumption, Production, Inflation, and Interest Rates: A Synthesis", Journal of Financial Economics 16, 3-39.

Breeden, Douglas T., Michael R. Gibbons, and Robert H. Litzenberger, 1989, "Empirical Tests of the Consumption-Oriented CAPM", Journal of Finance 44, 231-262.

Brown, David P. and Michael R. Gibbons, 1985, "A Simple Econometric Approach for Utility-Based Asset Pricing Models", Journal of Finance 40, 359-381.

Campbell, John Y., 1987, "Stock Returns and the Term Structure", Journal of Financial Economics 18, 373-399.

Campbell, John Y., 1991a, "A Variance Decomposition for Stock Returns", the H.G. Johnson Lecture to the Royal Economic Society, Economic Journal 101, 157-179.

Campbell, John Y., 1991b, "Inspecting the Mechanism: An Analytical Approach to the Stochastic Growth Model", unpublished paper, Princeton University.

Campbell, John Y. and Hyeng K. Koo, 1992, "A Numerical Solution for the Consumption Wealth Ratio in a Model with Nonexpected Utility Using Nystrom's Method", unpublished paper, Princeton University.

Campbell, John Y. and N. Gregory Mankiw, 1989, "Consumption, Income, and Interest Rates: Reinterpreting the Time Series Evidence", in Olivier J. Blanchard and Stanley Fischer eds. NBER Mactoeconomics Annual 1989, 185-216, Cambridge, MA: MIT Press.

Campbell, John Y. and Robert J. Shiller, 1988a, "The Dividend-Price Ratio and Expectations of Future Dividends and Discount Factors", Review of Financial Studies $1,195-228$.

Campbell, John Y. and Robert J. Shiller, 1988b, "Stock Prices, Earnings, and Expected Dividends", Journal of Finance 43, 661-676.

Chen, Nai-fu, Richard Roll, and Stephen A. Ross, 1986, "Economic Forces and the Stock Market", Journal of Business 59, 383-403.

Chen, Zhiwu, 1991, "Consumer Behavior and Asset Pricing When Taste Formation Depends on Wealth", Working Paper 7-91-7, Graduate School of Business, University of Wisconsin. 
Christiano, Lawrence J., 1988, "Why Does Inventory Investment Fluctuate So Much?", Journal of Monetary Economics 21, 247-280.

Constantinides, George, 1990, "Habit Formation: A Resolution of the Equity Premium Puzzle", Journal of Political Economy 98, 519-543.

Cox, John C., Jonathan E. Ingersoll, and Stephen A. Ross, 1985, "A Theory of the Term Structure of Interest Rates", Econometrica 53, 385-408.

Dunn, Kenneth B. and Kenneth J. Singleton, 1986, "Modelling the Term Structure of Interest Rates under Habit Formation and Durability of Goods", Journal of Financial Economics 17, 27-55.

Epstein, Lawrence and Stanley Zin, 1989, "Substitution, Risk Aversion, and the Temporal Behavior of Consumption and Asset Returns: A Theoretical Framework", Econometrica 57, 937-969.

Epstein, Lawrence and Stanley Zin, 1991, "Substitution, Risk Aversion, and the Temporal Behavior of Consumption and Asset Returns: An Empirical Analysis", Journal of Political Economy 99, 263-286.

Fama, Eugene F., 1970, "Multiperiod Consumption-Investment Decisions", American Economic Review 60, 163-174.

Fama, Eugene F. and Kenneth R. French, 1988a, "Permanent and Temporary Components of Stock Prices", Journal of Political Economy 96, 246-273.

Fama, Eugene F. and Kenneth R. French, 1988b, "Dividend Yields and Expected Stock Returns", Journal of Financial Economics 22, 3-25.

Fama, Eugene F. and Kenneth R. French, 1989, "Business Conditions and Expected Returns on Stocks and Bonds", Journal of Financial Economics 25, 23-49.

Fama, Eugene F. and G. William Schwert, "Asset Returns and Inflation", Journal of Financial Economics 5:115-146, 1977.

Ferson, Wayne E. and George M. Constantinides, 1989, "Habit Persistence and Durability in Aggregate Consumption: Empirical Tests", unpublished paper, University of Chicago.

French, Kenneth R., G. William Schwert, and Robert F. Stambaugh, 1987, "Expected Stock Returns and Volatility", Journal of Financial Economics 19, 3-29.

Friend, Irwin and Marshall E. Blume, 1975, "The Demand for Risky Assets", American Economic Review 65, 900-922.

Giovannini, Alberto and Philippe Jorion, "Time-Series Tests of a Non-Expected Utility Model of Asset Pricing", NBER Working Paper No. 3195, December 1989.

Giovannini, Alberto and Philippe Weil, "Risk Aversion and Intertemporal Substitution in the Capital Asset Pricing Model", NBER Working Paper No. 2824, January 1989.

Grossman, Sanford J., Angelo Melino, and Robert J. Shiller, 1987, "Estimating the Continuous-Time Consumption Based Asset Pricing Model", Journal of Business and Economic Statistics 5, 315-328. 
Grossman, Sanford J. and Robert J. Shiller, 1981, "The Determinants of the Variability of Stock Market Prices", American Economic Review 71, 222-227.

Hall, Robert E., 1988, "Intcrtemporal Substitution in Consumption", Journal of Po. litical Economy 96, 221-273.

Hansen, Lars Peter and Kenneth J. Singleton, 1982, "Generalized Instrumental Variables Estimation of Nonlinear Rational Expectations Models", Econometrica 50, 1269-1285.

Hansen, Lars Peter and Kenneth J. Singleton, 1983, "Stochastic Consumption, Risk Aversion, and the Temporal Behavior of Asset Returns", Journal of Political Econ. omy $91,249-265$.

Heaton, John, 1990, "An Empirical Investigation of Asset Pricing with Temporally Dependent Preference Specifications", unpublished paper, MIT.

Ingersoll, Jonathan E., Jr., 1987, Theory of Financial Decision Making, Rowman and Littlefield: Totowa, NJ.

Kandel, Shmuel and Robert F. Stambaugh, 1991, "Asset Returns and Intertemporal Preferences", Journal of Monetary Economics 27, 39-71.

Keim, Donald B. and Robert F. Stambaugh, "Predicting Returns in the Stock and Bond Markets", Journal of Financial Economics 17:357-390, December 1986.

King, Robert G., Charles I. Plosser, and Sergio T. Rebelo, 1987, "Production, Growth and Business Cycles: Technical Appendix ${ }^{n}$, unpublished paper, University of Rochester.

Kocherlakota, Narayana, 1990, "Disentangling the Coefficient of Relative Risk Aversion from the Elasticity of Intertemporal Substitution: An Irrelevance Result", Journal of Finance 45, 175-190.

Kreps, David, and E. Porteus, 1978, "Temporal Resolution of Uncertainty and Dynamic Choice Theory", Econometrica 46, 185-200.

Lucas, Robert E. Jr., 1978, "Asset Prices in an Exchange Economy", Econometrica 46, 1429-1446.

Mankiw, N. Gregory and Matthew D. Shapiro, 1986, "Risk and Return: Consumption versus Market Beta", Review of Economics and Statistics 68, 452-459.

Mankiw, N. Gregory and Stephen P. Zeldes, 1991, "The Consumption of Stockholders and Non-Stockholders", Journal of Financial Economics 29, 97-112.

Mehra, Rajnish and Edward Prescott, 1985, "The Equity Premium Puzzle", Journal of Monetary Economics 15, 145-161.

Merton, Robert C., 1969, "Lifetime Portfolio Selection Under Uncertainty: The Continuous Time Case", Review of Economics and Statistics 51, 247-257. Reprinted as Chapter 4 in Merton (1990).

Merton, Robert C., 1971, "Optimum Consumption and Portfolio Rules in a ContinuousTime Model", Journal of Economic Theory 3, 373-413. Reprinted as Chapter 5 in Merton (1990). 
Merton, Robert C., 1973, "An Intertemporal Capital Asset Pricing Model", Econometrica 41, 867-887. Reprinted as Chapter 15 in Merton (1990).

Merton, Robert C., 1980, "On Estimating the Expected Return on the Market: An Exploratory Analysis", Journal of Financial Economics 8, 323-361.

Merton, Robert C., 1990, Continuous Time Finance, Basil Blackwell: Cambridge, MA.

Poterba, James M. and Lawrence H. Summers, "Mean Reversion in Stock Prices: Evidence and Implications", Journal of Financial Economics 22:27-59, October 1988.

Restoy, Fernando, 1991, "Optimal Portfolio Policies Under Time-Dependent Returns", unpublished paper, Harvard University.

Roll, Richard R., 1977, “A Critique of the Asset Pricing Theory's Tests, Part 1: On Past and Potential Testability of the Theory", Journal of Financial Economics 4, 129-176.

Roll, Richard R. and Stephen A. Ross, 1980, "An Empirical Investigation of the Arbitrage Pricing Theory", Journal of Finance 35, 1073-1103.

Ross, Stephen A., 1976, "Arbitrage Theory of Capital Asset Pricing", Journal of Economic Theory "13, 341-360.

Rubinstein, Mark, 1981, "A Discrete-Time Synthesis of Financial Theory", in Haim Levy ed. Research in Finance 3, JAI Press: Greenwich, CT.

Samuelson, Paul A., 1969, "Lifetime Portfolio Selection by Dynamic Stochastic Programming", Review of Economics and Statistics 51, 239-246.

Svensson, Lars E.O., 1989, "Portfolio Choice with Non-Expected Utility in Continuous Time", Economics Letters 30, 313-317.

Tauchen, George and Robert Hussey, 1991, "Quadrature-Based Methods for Obtaining Approximate Solutions to Nonlinear Asset Pricing Models", Economctrica 59, 371 . 396.

Weil, Philippe, 1987, "Non-Expected Utility in Macroeconomics", unpublished paper, Harvard University.

Weil, Philippe, 1989, "The Equity Premium Puzzle and the Risk-Free Rate Puzzle", Journal of Monetary Economics 24, 401-421.

Wheatley, Simon, 1988, "Some Tests of the Consumption-Based Asset Pricing Model", Journal of Monetary Economics 22, 193-215.

Wilcox, David A., 1989, "What Do We Know About Consumption?", unpublished paper, Board of Governors of the Federal Reserve System. 
Table 1

Mean Value Function with Percentage Losses from Loglinear Consumption Rules

\begin{tabular}{|c|c|c|c|c|c|c|}
\hline \multirow[b]{2}{*}{$\gamma=$} & \multicolumn{6}{|c|}{$\sigma=$} \\
\hline & 0.05 & 0.50 & 1.00 & 2.00 & 3.00 & 4.00 \\
\hline 0.00 & $\left.\begin{array}{c}0.608 \\
(0.002 \\
0.238\end{array}\right)$ & $\begin{array}{c}0.612 \\
(0.000) \\
0.002)\end{array}$ & $\begin{array}{c}0.617 \\
(0.000) \\
0.000)\end{array}$ & $\begin{array}{c}0.629 \\
(0.000) \\
0.010)\end{array}$ & $\begin{array}{c}0.646 \\
(0.001 \\
0.137)\end{array}$ & $\left.\begin{array}{c}0.670 \\
(0.003) \\
0.724\end{array}\right)$ \\
\hline 0.50 & $\begin{array}{c}0.574 \\
(0.002) \\
(0.048)\end{array}$ & $\begin{array}{c}0.576 \\
(0.000) \\
(0.000)\end{array}$ & $\begin{array}{c}0.578 \\
(0.000) \\
0.000)\end{array}$ & $\begin{array}{c}0.583 \\
(0.000) \\
0.002)\end{array}$ & $\begin{array}{c}0.589 \\
(0.001) \\
0.023)\end{array}$ & $\begin{array}{c}0.596 \\
(0.003) \\
0.102)\end{array}$ \\
\hline 1.00 & $\begin{array}{c}0.540 \\
(0.002) \\
0.006)\end{array}$ & $\begin{array}{c}0.541 \\
(0.000) \\
(0.000)\end{array}$ & $\begin{array}{c}0.542 \\
(0.000) \\
0.000)\end{array}$ & $\begin{array}{c}0.543 \\
(0.000) \\
0.000)\end{array}$ & $\begin{array}{c}0.544 \\
(0.001) \\
0.002)\end{array}$ & $\begin{array}{c}0.546 \\
(0.002) \\
0.008)\end{array}$ \\
\hline 2.00 & $\begin{array}{c}0.473 \\
(0.004) \\
0.021)\end{array}$ & $\begin{array}{c}0.474 \\
(0.000) \\
(0.000)\end{array}$ & $\begin{array}{c}0.475 \\
(0.000) \\
0.000)\end{array}$ & $\begin{array}{c}0.477 \\
(0.000) \\
0.000)\end{array}$ & $\begin{array}{c}0.479 \\
(0.001) \\
0.004)\end{array}$ & $\left.\begin{array}{c}0.481 \\
(0.002 \\
0.016\end{array}\right)$ \\
\hline 3.00 & $\begin{array}{c}0.407 \\
(0.007) \\
0.867)\end{array}$ & $\left.\begin{array}{c}0.412 \\
(0.000) \\
0.004\end{array}\right)$ & $\begin{array}{c}0.417 \\
(0.000) \\
0.000)\end{array}$ & $\begin{array}{c}0.426 \\
(0.000) \\
0.010)\end{array}$ & $\begin{array}{c}0.433 \\
(0.000) \\
(0.085)\end{array}$ & $\begin{array}{c}0.438 \\
(0.002) \\
0.268)\end{array}$ \\
\hline 4.00 & $\begin{array}{c}0.341 \\
(0.010) \\
(-)^{*}\end{array}$ & $\begin{array}{c}0.354 \\
(0.000) \\
0.029)\end{array}$ & $\begin{array}{c}0.366 \\
(0.000) \\
0.000)\end{array}$ & $\begin{array}{c}0.384 \\
(0.000) \\
(0.055)\end{array}$ & $\begin{array}{c}0.397 \\
(0.000) \\
0.426)\end{array}$ & $\begin{array}{c}0.407 \\
(0.001) \\
(1.21)\end{array}$ \\
\hline
\end{tabular}

The first number in each block is the mean value function, expressed as a percentage of wealth. The second and third numbers are losses from using loglinear approximate consumption rules with the true $\rho$ and $\rho=\beta$, respectively, expressed as percentages of the exact mean value function.

* Calculation of loss from approximate consumption rule failed to converge. 
Table 2

Mean Optimal Consumption-Wealth Ratio with Percentage Errors of Loglinear Consumption Rules

\begin{tabular}{|c|c|c|c|c|c|c|}
\hline \multirow[b]{2}{*}{$\gamma=$} & \multicolumn{6}{|c|}{$\sigma=$} \\
\hline & 0.05 & 0.50 & 1.00 & 2.00 & 3.00 & 4.00 \\
\hline 0.00 & $\begin{array}{c}0.603 \\
(0.090) \\
(1.40)\end{array}$ & $\begin{array}{c}0.561 \\
(0.017) \\
0.396)\end{array}$ & $\begin{array}{c}0.514 \\
(0.000) \\
0.000)\end{array}$ & $\begin{array}{c}0.421 \\
(0.170) \\
(2.01)\end{array}$ & $\begin{array}{c}0.329 \\
(0.635) \\
(9.55)\end{array}$ & $\begin{array}{l}0.237 \\
(1.43) \\
27.9)\end{array}$ \\
\hline 0.50 & $\begin{array}{c}0.571 \\
(0.103) \\
(0.659)\end{array}$ & $\begin{array}{c}0.544 \\
(0.024) \\
(0.183)\end{array}$ & $\left.\begin{array}{c}0.514 \\
(0.000) \\
0.000\end{array}\right)$ & $\begin{array}{c}0.455 \\
(0.153) \\
(0.868)\end{array}$ & $\begin{array}{c}0.396 \\
(0.583) \\
(3.76)\end{array}$ & $\begin{array}{c}0.336 \\
(1.30) \\
(9.45)\end{array}$ \\
\hline 1.00 & $\begin{array}{c}0.539 \\
(0.117) \\
(0.228)\end{array}$ & $\begin{array}{c}0.527 \\
(0.032) \\
0.063)\end{array}$ & $\left.\begin{array}{c}0.514 \\
(0.000) \\
0.000\end{array}\right)$ & $\begin{array}{c}0.488 \\
(0.134) \\
0.265)\end{array}$ & $\begin{array}{c}0.463 \\
(0.535) \\
(1.08)\end{array}$ & $\begin{array}{l}0.437 \\
(1.21) \\
(2.49)\end{array}$ \\
\hline 2.00 & $\begin{array}{c}0.475 \\
(0.151) \\
0.439)\end{array}$ & $\begin{array}{c}0.494 \\
(0.049) \\
0.127\end{array}$ & $\begin{array}{c}0.514 \\
(0.000) \\
0.000)\end{array}$ & $\begin{array}{c}0.556 \\
(0.103) \\
0.393)\end{array}$ & $\begin{array}{c}0.597 \\
(0.470) \\
(1.59)\end{array}$ & $\begin{array}{l}0.639 \\
(1.10) \\
(3.54)\end{array}$ \\
\hline 3.00 & $\begin{array}{c}0.412 \\
(0.195) \\
(2.44)\end{array}$ & $\begin{array}{c}0.460 \\
(0.068) \\
0.642)\end{array}$ & $\begin{array}{c}0.514 \\
(0.000) \\
0.000)\end{array}$ & $\begin{array}{c}0.623 \\
(0.078) \\
(1.97)\end{array}$ & $\begin{array}{c}0.733 \\
(0.427) \\
(7.42)\end{array}$ & $\begin{array}{l}0.843 \\
(1.04) \\
15.9)\end{array}$ \\
\hline 4.00 & $\begin{array}{c}0.348 \\
(0.254) \\
(6.95)\end{array}$ & $\begin{array}{c}0.427 \\
(0.091) \\
(1.68)\end{array}$ & $\begin{array}{c}0.514 \\
(0.000) \\
(0.000)\end{array}$ & $\begin{array}{c}0.691 \\
(0.059) \\
(4.77)\end{array}$ & $\begin{array}{c}0.869 \\
(0.397) \\
(17.5)\end{array}$ & $\begin{array}{c}1.05 \\
(0.991) \\
(37.6)\end{array}$ \\
\hline
\end{tabular}

The first number in each block is the mean optimal consumption-wealth ratio, expressed as a percentage of wealth. The second and third numbers are the differences between the mean approximate consumption-wealth ratios and the mean optimal consumption-wealth ratio, where the approximations use the true $\rho$ and $\rho=\beta$ respectively, expressed as percentages of the mean optimal consumption-wealth ratio. 
Table 3

Standard Deviation of Optimal Log Consumption-Wealth Ratio with Percentage Errors of Loglinear Consumption Rules

\begin{tabular}{|c|c|c|c|c|c|c|}
\hline \multirow[b]{2}{*}{$\gamma=$} & \multicolumn{6}{|c|}{$\sigma=$} \\
\hline & 0.05 & 0.50 & 1.00 & 2.00 & 3.00 & 4.00 \\
\hline 0.00 & $\begin{array}{c}0.048 \\
(0.760) \\
(1.20)\end{array}$ & $\begin{array}{c}0.025 \\
(0.756) \\
0.986)\end{array}$ & $\begin{array}{l}0.000 \\
(\square)\end{array}$ & $\begin{array}{c}0.051 \\
(0.750 \\
0.287)\end{array}$ & $\begin{array}{c}0.103 \\
(0.749) \\
(-0.178)\end{array}$ & $\begin{array}{c}0.155 \\
(0.748) \\
(-0.640)\end{array}$ \\
\hline 0.50 & $\begin{array}{c}0.048 \\
(0.759) \\
(1.04)\end{array}$ & $\left.\begin{array}{c}0.025 \\
(0.755) \\
0.902\end{array}\right)$ & $\begin{array}{l}0.000 \\
(-)\end{array}$ & $\begin{array}{c}0.051 \\
(0.752) \\
0.454)\end{array}$ & $\begin{array}{c}0.102 \\
(0.755) \\
0.156)\end{array}$ & $\begin{array}{c}0.154 \\
(0.760) \\
(-0.141)\end{array}$ \\
\hline 1.00 & $\begin{array}{c}0.048 \\
(0.758) \\
(0.876)\end{array}$ & $\left.\begin{array}{c}0.025 \\
(0.754) \\
0.818\end{array}\right)$ & $\begin{array}{l}0.000 \\
(\square)\end{array}$ & $\begin{array}{c}0.051 \\
(0.754) \\
0.622)\end{array}$ & $\begin{array}{c}0.102 \\
(0.760) \\
(0.492)\end{array}$ & $\begin{array}{c}0.153 \\
(0.771) \\
(0.361)\end{array}$ \\
\hline 2.00 & $\begin{array}{c}0.048 \\
(0.754) \\
(0.558)\end{array}$ & $\left.\begin{array}{c}0.025 \\
(0.753) \\
0.650\end{array}\right)$ & $\begin{array}{l}0.000 \\
(-)\end{array}$ & $\begin{array}{c}0.051 \\
(0.757) \\
0.958)\end{array}$ & $\begin{array}{c}0.101 \\
(0.768) \\
(1.16)\end{array}$ & $\begin{array}{c}0.151 \\
(0.788) \\
(1.37)\end{array}$ \\
\hline 3.00 & $\begin{array}{c}0.049 \\
(0.750) \\
0.239)\end{array}$ & $\left.\begin{array}{c}0.026 \\
(0.751) \\
0.482\end{array}\right)$ & $\begin{array}{l}0.000 \\
(-)\end{array}$ & $\begin{array}{c}0.051 \\
(0.759) \\
(1.30)\end{array}$ & $\begin{array}{c}0.101 \\
(0.773) \\
(1.84)\end{array}$ & $\begin{array}{c}0.150 \\
(0.798) \\
(2.39)\end{array}$ \\
\hline 4.00 & $\begin{array}{c}0.049 \\
(0.746) \\
(-0.078)\end{array}$ & $\begin{array}{c}0.026 \\
(0.749) \\
(0.314)\end{array}$ & $\begin{array}{l}0.000 \\
(-)\end{array}$ & $\begin{array}{c}0.050 \\
(0.760) \\
(1.63)\end{array}$ & $\begin{array}{c}0.100 \\
(0.775) \\
(2.52)\end{array}$ & $\begin{array}{c}0.148 \\
(0.802) \\
(3.42)\end{array}$ \\
\hline
\end{tabular}

The first number in each block is the standard deviation of the optimal log consumption-wealth ratio. The second and third numbers are the differences between the standard deviations of approximate log consumption-wealth ratios and the standard deviation of the optimal log consumption-wealth ratio, where the approximations use the true $\rho$ and $\rho=\beta$ respectively, expressed as percentages of the optimal standard deviation. 
Table 4

Standard Deviation of Optimal Log Consumption Growth Rate with Percentage Errors of Loglinear Consumption Rules

\begin{tabular}{|c|c|c|c|c|c|c|}
\hline \multirow[b]{2}{*}{$\gamma=$} & \multicolumn{6}{|c|}{$\sigma=$} \\
\hline & 0.05 & 0.50 & 1.00 & 2.00 & 3.00 & 4.00 \\
\hline 0.00 & $\begin{array}{c}0.037 \\
(-0.251) \\
-0.394\end{array}$ & $\begin{array}{c}0.045 \\
(-0.175) \\
-0.228\end{array}$ & $\begin{array}{c}0.057 \\
(0.000) \\
0.000)\end{array}$ & $\begin{array}{c}0.085 \\
(0.260) \\
0.100)\end{array}$ & $\begin{array}{c}0.115 \\
(0.401) \\
(-0.088)\end{array}$ & $\begin{array}{c}0.147 \\
(0.482) \\
(-0.392)\end{array}$ \\
\hline 0.50 & $\left(\begin{array}{c}0.037 \\
(-0.251) \\
-0.341\end{array}\right)$ & $\left.\begin{array}{c}0.045 \\
(-0.175) \\
-0.209\end{array}\right)$ & $\begin{array}{c}0.057 \\
(0.000) \\
0.000)\end{array}$ & $\begin{array}{c}0.085 \\
(0.260) \\
(0.158)\end{array}$ & $\begin{array}{c}0.115 \\
(0.403) \\
0.087)\end{array}$ & $\begin{array}{c}0.146 \\
(0.490) \\
(-0.081)\end{array}$ \\
\hline 1.00 & $\begin{array}{c}0.037 \\
(-0.250) \\
-0.289)\end{array}$ & $\left(\begin{array}{c}0.045 \\
-0.175 \\
-0.189\end{array}\right)$ & $\begin{array}{c}0.057 \\
(0.000) \\
0.000)\end{array}$ & $\begin{array}{c}0.085 \\
(0.260) \\
(0.215)\end{array}$ & $\begin{array}{c}0.115 \\
(0.405) \\
(0.263)\end{array}$ & $\begin{array}{c}0.146 \\
(0.496) \\
0.235)\end{array}$ \\
\hline 2.00 & $\left.\begin{array}{c}0.037 \\
-0.249 \\
-0.184\end{array}\right)$ & $\left.\begin{array}{c}0.045 \\
(-0.175) \\
-0.151\end{array}\right)$ & $\begin{array}{c}0.057 \\
(0.000) \\
0.000)\end{array}$ & $\left.\begin{array}{c}0.085 \\
(0.261) \\
(0.331\end{array}\right)$ & $\begin{array}{c}0.114 \\
(0.408) \\
(0.620)\end{array}$ & $\begin{array}{c}0.145 \\
(0.506) \\
0.882)\end{array}$ \\
\hline 3.00 & $\left.\begin{array}{c}0.037 \\
-0.247 \\
-0.080\end{array}\right)$ & $\left.\begin{array}{c}0.045 \\
(-0.174) \\
-0.112\end{array}\right)$ & $\begin{array}{c}0.057 \\
(0.000) \\
(0.000)\end{array}$ & $\begin{array}{c}0.085 \\
(0.261) \\
(0.447)\end{array}$ & $\begin{array}{c}0.114 \\
(0.410) \\
(0.988)\end{array}$ & $\begin{array}{c}0.144 \\
(0.511) \\
(1.56)\end{array}$ \\
\hline 4.00 & $\begin{array}{c}0.037 \\
(-0.246) \\
(0.025)\end{array}$ & $\begin{array}{c}0.045 \\
(-0.174) \\
-0.074)\end{array}$ & $\begin{array}{c}0.057 \\
(0.000) \\
(0.000)\end{array}$ & $\begin{array}{c}0.085 \\
(0.261) \\
(0.565)\end{array}$ & $\begin{array}{c}0.114 \\
(0.410) \\
(1.37)\end{array}$ & $\begin{array}{c}0.143 \\
(0.512) \\
(2.29)\end{array}$ \\
\hline
\end{tabular}

The first number in each block is the standard deviation of the optimal log consumption growth rate. The second and third numbers are the differences between the standard deviations of approximate log consumption growth rates and the standard deviation of the optimal log consumption growth rate, where the approximations use the true $\rho$ and $\rho=\beta$ respectively, expressed as percentages of the optimal standard deviation. 


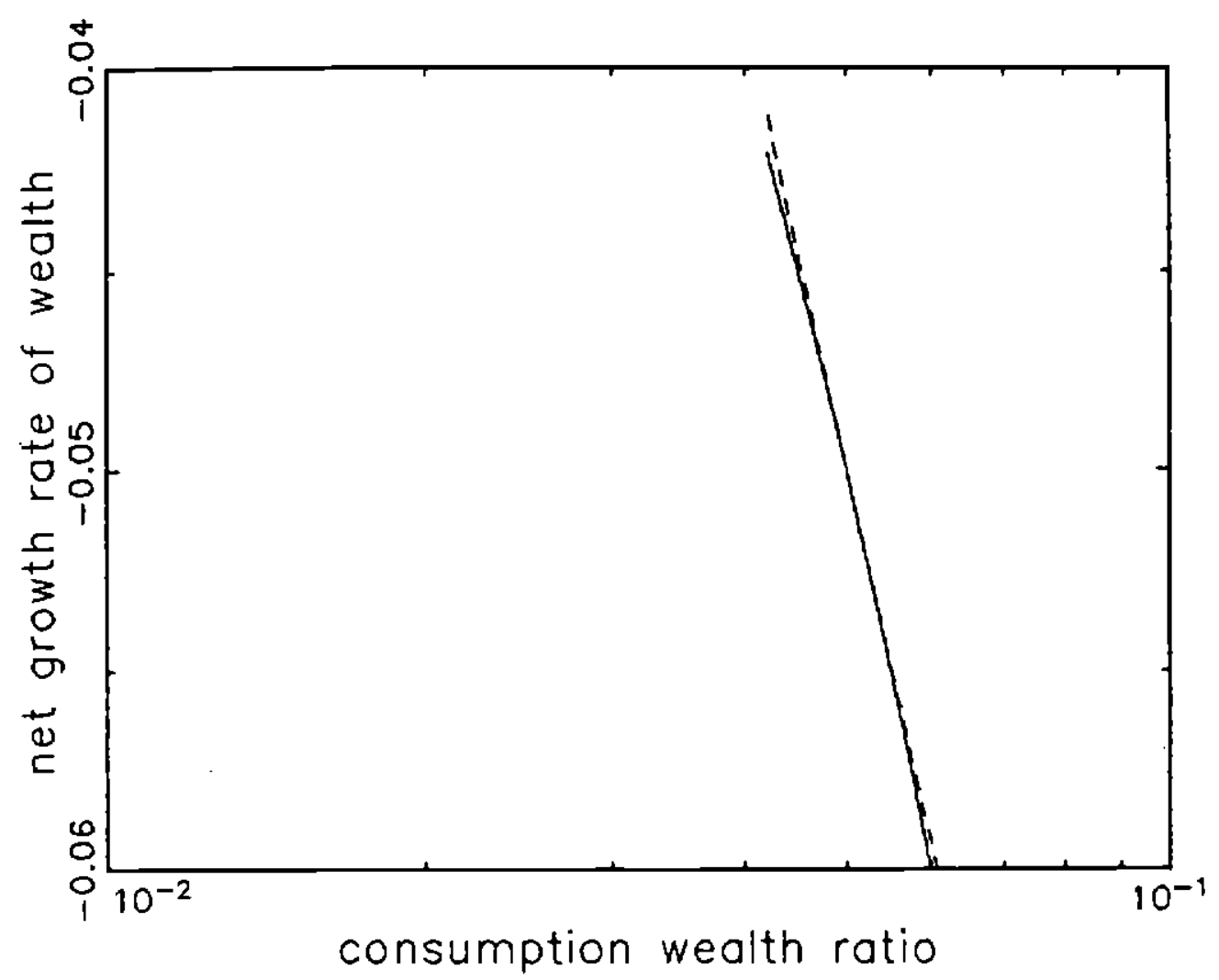

Figure 1: Loglinear Approximation for $\sigma=2$

The horizontal axis shows the annualized consumption-wealth ratio, using a log scale from $1 \%$ to $10 \%$. The vertical axis shows the annualized net growth rate of wealth $\Delta w_{t+1}-r_{m, t+1}$. The solid curve is the exact relationship $\Delta w_{t+1}-r_{m, t+1}=$ $\log \left(1-\exp \left(c_{t}-w_{t}\right)\right)$, while the dashed straight line is the approximation given by equation (2.5) in the text. These curves are plotted over a range from three standard deviations below to three standard deviations above the mean log consumption-wealth ratio. The standard deviation of the log consumption-wealth ratio is calculated from equation (5.2) in the text using the parameter values discussed in section 5 and assuming $\sigma=2$. 


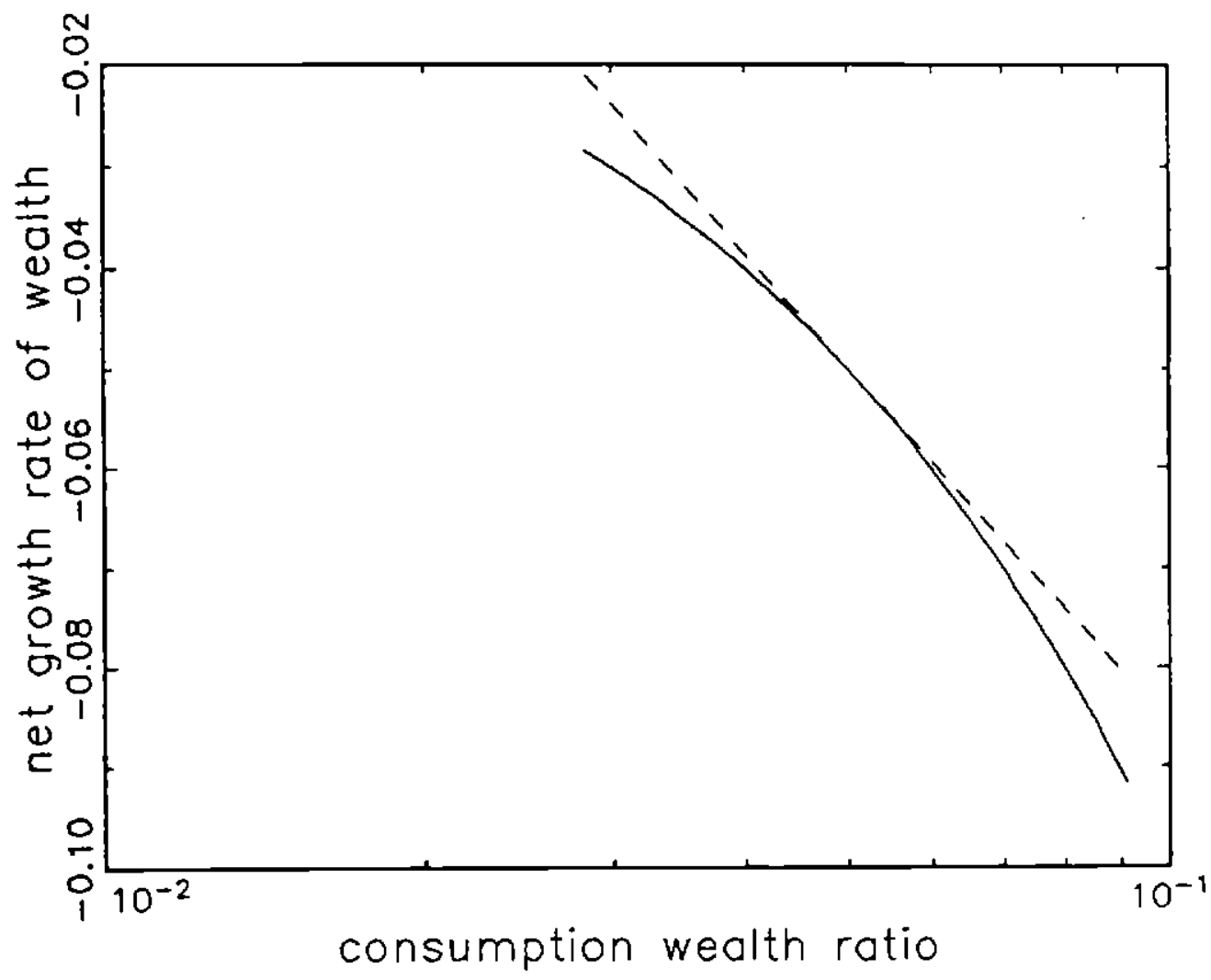

Figure 2: Loglinear Approximation for $\sigma=4$

The horizontal axis shows the annualized consumption-wealth ratio, using a log scale from $1 \%$ to $10 \%$. The vertical axis shows the annualized net growth rate of wealth $\Delta w_{t+1}-r_{m, t+1}$. The solid curve is the exact relationship $\Delta w_{t+1}-r_{m, t+1}=$ $\log \left(1-\exp \left(c_{t}-w_{t}\right)\right)$, while the dashed straight line is the approximation given by equation (2.5) in the text. These curves are plotted over a range from three standard deviations below to three standard deviations above the mean log consumption-wealth ratio. The standard deviation of the $\log$ consumption-wealth ratio is calculated from equation (5.2) in the text using the parameter values discussed in section 5 and assuming $\sigma=4$. 


\begin{tabular}{|c|c|}
\hline Number & Author \\
\hline 3924 & $\begin{array}{l}\text { David Hartis } \\
\text { Randall Morck } \\
\text { Joel SIemrod } \\
\text { Bemard Yeung }\end{array}$ \\
\hline 3925 & $\begin{array}{l}\text { Rosanne Altshuler } \\
\text { T. Scott Newlon }\end{array}$ \\
\hline 3926 & Frank R. Lichtenberg \\
\hline 3927 & $\begin{array}{l}\text { Lawrence F. Katz } \\
\text { Kevin M. Murphy }\end{array}$ \\
\hline 3928 & Daniel S. Hamermesh \\
\hline 3929 & Benjamin M. Friedman \\
\hline 3930 & James R. Hines Jr. \\
\hline 3931 & $\begin{array}{l}\text { Bemard Dumas } \\
\text { Lars E.O. Svensson }\end{array}$ \\
\hline 3932 & $\begin{array}{l}\text { Andrew B. Lyon } \\
\text { Robert M. Schwab }\end{array}$ \\
\hline 3933 & $\begin{array}{l}\text { Donald Haurin } \\
\text { Patric Hendershot } \\
\text { Dongwook Kim }\end{array}$ \\
\hline 3934 & Frederic S. Mishkin \\
\hline 3935 & Donald Siegel \\
\hline 3936 & David Romer \\
\hline 3937 & Mark Schankerman \\
\hline 3938 & Jonathan Skinner \\
\hline 3939 & $\begin{array}{l}\text { David H. Good } \\
\text { M. Ishaq Nadin } \\
\text { Robin C. Slckles }\end{array}$ \\
\hline
\end{tabular}

Tile

$\underline{\text { Date }}$

Income Shifting in U.S. Multinational

$12 / 91$

Corporations

The Effects of U.S. Tax Policy on the

$12 / 91$ Income Repatriation Patterns of U.S.

Multinational Corporations

Labor Market Institutions, Liquidity

$12 / 91$

Constraints, and Macroeconomic Stability

Changes in Relative Wages, 1963-1987:

Supply and Demand Factors

The Appointment-Book Problem and Commitment with Applications to Refereeing and Medicine

$12 / 91$

How Does It Matter?

$12 / 91$

On the Sensitivity of $R \& D$ to Delicate Tax Changes: The Behavior of U.S. Multinationals in the $1980 \mathrm{~s}$

How Long Do Unilateral Target Zones Last?

Consumption Taxes in a Life-Cycle

Framework: Are Sin Taxes Regressive?

$12 / 91$

Local House Price Indexes: 1982-1991

$12 / 91$

Anatomy of a Financial Crisis

$12 / 91$

Errors in Output Deflators Revisited:

Unit Values and the PPI

Openness and Inflation: Theory and Evidence

$12 / 91$

Revisions of Investment Plans and the

$12 / 91$

Stock Market Rate of Retum

Individual Retirement Accounts: A

$12 / 91$

Review of the Evidence

The Structure of Production. Technical Change

$12 / 91$ and Efficiency in a Multi-Product Industry: An Application to U.S. Airlines 


\begin{tabular}{|c|c|c|c|}
\hline Number & Author & Tille & $\underline{\text { Date }}$ \\
\hline 3940 & James M. Poterba & $\begin{array}{l}\text { Why Didn't the Tax Reform Act of } 1986 \\
\text { Raise Corporate Taxes? }\end{array}$ & $12 / 91$ \\
\hline 3941 & $\begin{array}{l}\text { Robert P. Inman } \\
\text { Daniel L. Rubinfeld }\end{array}$ & $\begin{array}{l}\text { Fiscal Federalism in Europe: Lessons } \\
\text { From the United States Experience }\end{array}$ & $12 / 91$ \\
\hline 3942 & $\begin{array}{l}\text { Paul Asquith } \\
\text { Robert Gertner } \\
\text { David Scharfstein }\end{array}$ & $\begin{array}{l}\text { Anatomy of Financial Distress: An } \\
\text { Examination of Junk-Bond Issuers }\end{array}$ & $12 / 91$ \\
\hline 3943 & Maurice Obstfeld & The Adjustment Mechanism & $12 / 91$ \\
\hline 3944 & $\begin{array}{l}\text { Alessandro Missale } \\
\text { Olivier Jean Blanchard }\end{array}$ & The Debt Burden and Debt Maturily & $12 / 91$ \\
\hline 3945 & Leslie E. Papke & $\begin{array}{l}\text { Tax Policy and Urban Development: } \\
\text { Evidence From an Enterprise Zone Program }\end{array}$ & $12 / 91$ \\
\hline 3946 & $\begin{array}{l}\text { Joseph E. Gagnon } \\
\text { Andrew K. Rose }\end{array}$ & $\begin{array}{l}\text { How Pervasive is the Product Cycle? } \\
\text { The Empirical Dynamics of American and } \\
\text { Japanese Trade Flows }\end{array}$ & $01 / 92$ \\
\hline 3947 & Dani Rodrik & $\begin{array}{l}\text { The Rush to Free Trade in the Developing World: } \\
\text { Why So Late? Why Now? Will It Last? }\end{array}$ & $01 / 92$ \\
\hline 3948 & $\begin{array}{l}\text { John F. Helliwell } \\
\text { Alan Chung }\end{array}$ & $\begin{array}{l}\text { Convergence and Growth Linkages Between } \\
\text { North and South }\end{array}$ & $01 / 92$ \\
\hline 3949 & $\begin{array}{l}\text { Tamim Bayoumi } \\
\text { Barry Eichengreen }\end{array}$ & $\begin{array}{l}\text { Shocking Aspects of European Monetary } \\
\text { Unification }\end{array}$ & $01 / 92$ \\
\hline 3950 & $\begin{array}{l}\text { Tamim Bayoumi } \\
\text { Barry Eichengreen }\end{array}$ & $\begin{array}{l}\text { Is There a Conflict Between EC Enlargement } \\
\text { and European Monetary Unification? }\end{array}$ & $01 / 92$ \\
\hline 3951 & Kathryn M. Dominguez & $\begin{array}{l}\text { The Role of International Organizations } \\
\text { in the Bretton Woods System }\end{array}$ & $01 / 92$ \\
\hline 3952 & $\begin{array}{l}\text { Janet Currie } \\
\text { Henry S. Farber }\end{array}$ & $\begin{array}{l}\text { ls Arbitration Addictive? Evidence From the } \\
\text { Laboratory and the Field }\end{array}$ & $01 / 92$ \\
\hline 3953 & Joshua Aizenman & $\begin{array}{l}\text { Exchange Rate Flexibility. Volatility, and the } \\
\text { Patterns of Domestic and Foreign Direct Investment }\end{array}$ & $01 / 92$ \\
\hline 3954 & $\begin{array}{l}\text { Zvi Bodie } \\
\text { Robert C. Merton } \\
\text { William F. Samuelson }\end{array}$ & $\begin{array}{l}\text { Labor Supply Flexibility and Portfolio Choice } \\
\text { in a Life-Cycle Model }\end{array}$ & $01 / 92$ \\
\hline 3955 & $\begin{array}{l}\text { Zhaohui Chen } \\
\text { Alberto Giovannini }\end{array}$ & $\begin{array}{l}\text { Estimating Expected Exchange Rates Under } \\
\text { Target Zones }\end{array}$ & $01 / 92$ \\
\hline
\end{tabular}




\begin{tabular}{|c|c|c|c|}
\hline Number & Author & Title & $\underline{\text { Date }}$ \\
\hline 3956 & $\begin{array}{l}\text { Bronwyn H. Hall } \\
\text { Jacques Mairesse }\end{array}$ & $\begin{array}{l}\text { Exploning the Relationship Between R\&D and } \\
\text { Productivity in French Manufacturing Firms }\end{array}$ & $01 / 92$ \\
\hline 3957 & Edward E. Leamcr & Testing Trade Theory & $01 / 92$ \\
\hline 3958 & Louis Kaplow & A Model of Optinal Complexity of Rules & $01 / 92$ \\
\hline 3959 & Sule Ozler & Have Commercial Banks Ignored History? & $01 / 92$ \\
\hline 3960 & $\begin{array}{l}\text { Sule Ozler } \\
\text { Dani Rodrik }\end{array}$ & $\begin{array}{l}\text { Extemal Shocks, Politics and Privale Investment: } \\
\text { Some Theory and Empirical Evidence }\end{array}$ & $01 / 92$ \\
\hline 3961 & $\begin{array}{l}\text { Sule Ozler } \\
\text { Harry Huizinga }\end{array}$ & $\begin{array}{l}\text { Bank Exposure, Capital and Secondary Market } \\
\text { Discounts On Developing Country Debt }\end{array}$ & $01 / 92$ \\
\hline 3962 & $\begin{array}{l}\text { Martin Feldstein } \\
\text { Andrew Samwick }\end{array}$ & Social Security Rules and Marginal Tax Rates & $01 / 92$ \\
\hline 3963 & James M. Poterba & Taxation and Housing: Old Questions, New Answers & $01 / 92$ \\
\hline 3964 & $\begin{array}{l}\text { David M. Cutler } \\
\text { Lawrence F. Katz }\end{array}$ & $\begin{array}{l}\text { Rising Inequality? Changes in the Distribution of } \\
\text { Income and Consumption in the } 1980 \text { s }\end{array}$ & $01 / 92$ \\
\hline 3965 & $\begin{array}{l}\text { Victor Zamowitz } \\
\text { Phillip Braun }\end{array}$ & $\begin{array}{l}\text { Twenty-two Years of the NBER-ASA Quarterly } \\
\text { Economic Outlook Surveys: Aspects and Comparisons } \\
\text { of Forecasting Performance }\end{array}$ & $01 / 92$ \\
\hline 3966 & Martin Feldstein & The Budget and Trade Deficits Aren't Really Twins & $01 / 92$ \\
\hline 3967 & Alan J. Auerbach & On the Design and Reform of Capital Gains Taxation & $01 / 92$ \\
\hline 3968 & $\begin{array}{l}\text { Alberto Alesina } \\
\text { Philippe Weil }\end{array}$ & Menus of Linear Income Tax Schedules & $01 / 92$ \\
\hline 3969 & Robert J. Gordon & $\begin{array}{l}\text { Measuring the Aggregate Price Level: Implications } \\
\text { For Economic Performance and Policy }\end{array}$ & $01 / 92$ \\
\hline 3970 & Charles R. Hulten & $\begin{array}{l}\text { What is Productivity: Capacity or Welfare } \\
\text { Measurement? }\end{array}$ & $01 / 92$ \\
\hline 3971 & Charles R. Hulten & $\begin{array}{l}\text { Growth Accounting When Technical Change is } \\
\text { Embodied in Capital }\end{array}$ & $01 / 92$ \\
\hline 3972 & George J. Borjas & The Intergenerational Mobility of Immigrants & $01 / 92$ \\
\hline 3973 & $\begin{array}{l}\text { David E. Bloom } \\
\text { Richard B. Freeman }\end{array}$ & The Fall in Private Pension Coverage in the U.S. & $01 / 92$ \\
\hline 3974 & $\begin{array}{l}\text { Lawrence J. Christiano } \\
\text { Marin Eichenbaum }\end{array}$ & $\begin{array}{l}\text { Liquidity Effects and the Monelary Transmission } \\
\text { Mechanism }\end{array}$ & 92 \\
\hline
\end{tabular}




\begin{tabular}{|c|c|c|c|}
\hline Number & Author & Title & Date \\
\hline 3975 & Philippe Weil & $\begin{array}{l}\text { Equilibrium Asset Prices With Undiversifiable Labor } \\
\text { Income Risk }\end{array}$ & $01 / 92$ \\
\hline 3976 & $\begin{array}{l}\text { Miles Kimball } \\
\text { Philippe Weil }\end{array}$ & $\begin{array}{l}\text { Precautionary Saving and Consumption Smoothing } \\
\text { Across Time and Possibilities }\end{array}$ & $01 / 92$ \\
\hline 3977 & $\begin{array}{l}\text { G. Steven Olley } \\
\text { Ariel Pakes }\end{array}$ & $\begin{array}{l}\text { The Dynamics of Productivity in the } \\
\text { Telecommunications Equipment Industry }\end{array}$ & $01 / 92$ \\
\hline 3978 & $\begin{array}{l}\text { Janet Currie } \\
\text { Sheena McConnell }\end{array}$ & $\begin{array}{l}\text { The Impact of Collective Bargaining Legislation } \\
\text { On Disputes in the U.S. Public Sector: No Policy } \\
\text { May Be the Worst Policy }\end{array}$ & $01 / 92$ \\
\hline 3979 & Jeffrey I. Bemstein & $\begin{array}{l}\text { Information Spillovers, Margins, Scale and Scope: } \\
\text { With an Application to Canadian Life Insurance }\end{array}$ & $01 / 92$ \\
\hline 3980 & S. Lael Brainard & Sectoral Shifts and Unemployment in Interwar Britain & $01 / 92$ \\
\hline 3981 & $\begin{array}{l}\text { Catherine J. Morrison } \\
\text { Amy Ellen Schwarzz }\end{array}$ & State Infrastructure and Productive Performance & $01 / 92$ \\
\hline 3982 & Jeffrey I. Bemstein & $\begin{array}{l}\text { Price Margins and Capital Adjustment: Canadian Mill } \\
\text { Products and Pulp and Paper Industries }\end{array}$ & $01 / 92$ \\
\hline 3983 & Laurence Ball & Disinflation With Imperfect Credibility & $02 / 92$ \\
\hline 3984 & $\begin{array}{l}\text { Morris M. Kleiner } \\
\text { Roben T. Kudrle }\end{array}$ & $\begin{array}{l}\text { Do Tougher Licensing Provisions Limit Occupational } \\
\text { Entry? The Case of Dentistry }\end{array}$ & 02 \\
\hline 3985 & $\begin{array}{l}\text { Edward Montgomery } \\
\text { Kathryn Shaw }\end{array}$ & Pensions and Wage Premia & $02 / 92$ \\
\hline 3986 & $\begin{array}{l}\text { Casey B. Mulligan } \\
\text { Xavier Sala-i-Martin }\end{array}$ & $\begin{array}{l}\text { Transitional Dynamics in Two-Sector Models of } \\
\text { Endogenous Growth }\end{array}$ & $02 / 92$ \\
\hline 3987 & $\begin{array}{l}\text { Theodore Joyce } \\
\text { Andrew D. Racine } \\
\text { Naci Mocan }\end{array}$ & $\begin{array}{l}\text { The Consequences and Costs of Matemal Substance } \\
\text { Abuse in New York City: A Pooled Time-Series. } \\
\text { Cross-Section Analysis }\end{array}$ & $02 / 92$ \\
\hline 3988 & Roben J. Gordon & $\begin{array}{l}\text { Forward Into the Past: Productivity Retrogression } \\
\text { in the Electric Generating Industry }\end{array}$ & \\
\hline 3989 & John Y. Campbell & $\begin{array}{l}\text { Intentemporal Asset Pricing Without Consumption } \\
\text { Data }\end{array}$ & \\
\hline
\end{tabular}

Copies of the above working papers can be obtained by sending $\$ 5.00$ per copy (plus $\$ 10.00 /$ order for postage and handling for all locations outside the continental U.S.) to Working Papers, NBER, 1050 Massachusetts Avenue, Cambridge, MA 02138. Advance payment is required on all orders. Please make checks payable to the National Bureau of Economic Research. 